\title{
artículos
}

\section{A próposito de un agente de Pedro de Mena en Lucena: El pintor Bernabé Ximénez de Illescas}

\author{
Manuel García Luque
}

Universidad de Granada

RESUMEN

Una relectura de la carta que el pintor lucentino Bernabé Ximénez de Illescas envió en marzo de 1669 al escultor Pedro de Mena nos permite revisar la figura del primero y reflexionar sobre las complejas redes clientelares del segundo, que permitieron el arribo de obras de su taller a ámbitos periféricos como Lucena, donde hacemos un repaso de su obra documentada y atribuida.

PALABRAS CLAVE: Mena, Pedro de/ Ximénez de Illescas, Bernabé/ Málaga/ Lucena/ Escultura barroca/ Pintura barroca/ Escultura policromada/ Barroco/ Iconografía cristiana.

About the painter Bernabé Ximénez de Illescas, Sculptor Pedro de Mena 's

business agent in Lucena

ABSTRACT

Rereading the letter that the painter of Lucena Bernabé Ximénez de Illescas sent to the sculptor Pedro de Mena in March of 1669 allows us to review the figure of the first and reflect on the complex networks of clients of the latter. These networks allowed for pieces from his workshop to arrive at places on the periphery, like Lucena, where we can examine the work which is documented and attributed to him.

KEY WORDS: Mena, Pedro de/ Ximénez de Illescas, Bernabé/ Málaga/ Lucena/ Baroque sculpture/ Baroque painting/ Polychromed sculpture/ Baroque/ Christian Iconography.

La figura del pintor lucentino Bernabé Ximénez de Illescas (1608-1678) está aún por estudiar, debido fundamentalmente a las escasas referencias documentales hasta ahora conocidas y a la práctica inexistencia de obra conservada. Sin embargo, sí se conocían noticias sobre su actividad como pintor policromador, en alguna ocasión vinculado a importantes escultores de su época como Pedro Roldán o Pedro de Mena, síntoma del prestigio que pudo tener entre sus colegas y que le permitió entablar contactos profesionales con dos de los más reputados centros artísticos de Andalucía del siglo XVII: Sevilla y Málaga. En esta última ciudad pudo haber desarrollado parte de su actividad y conocer al escultor Pedro de Mena, a quien aparece encargando diversas esculturas desde Lucena (Córdoba). Tal fue el caso del Nazareno que Mena

* GARCÍA LUQUE, Manuel: "A próposito de un agente de Pedro de Mena en Lucena: El pintor Bernabé Ximénez de Illescas", en Boletín de Arte n 32-33, Departamento de Historia del Arte, Universidad de Málaga, 2011-2012, págs. 281-309. Fecha de recepción: Mayo de 2010 
realizó para la Cofradía de Pasión de dicha ciudad, documentado gracias a una carta que Bernabé Ximénez de Illescas envió al escultor el 29 de marzo de 1669. Una relectura del documento nos permite hacer una revisión sobre la figura de este pintor y analizar su papel como agente comercial de Mena.

\section{LA CARTA.}

El 30 de junio de 1903, el granadino Francisco de Paula Valladar publicaba en la revista La Alhambra, una noticia de sumo interés para el conocimiento de una de las cimas de nuestro Barroco: el tipógrafo Enrique López, responsable de la imprenta donde se imprimía la citada revista, le había facilitado unas cartas que por casualidad había hallado en el respaldo de un espejo antiguo ${ }^{1}$. Aquellas seis cartas, aunque escritas por diferentes remitentes, estaban dirigidas a un mismo destinatario, nada menos que al escultor Pedro de Mena y Medrano. Fechadas entre agosto de 1668 y abril de 1669, cabe suponer que formaron parte del archivo personal del artista y que, llegado el momento en que fueron consideradas inservibles, se emplearon como papelajos viejos, relegados al olvido y condenados a desaparecer. Sin embargo, quiso la diosa Fortuna que estas cartas fueran a parar a un hombre de fina sensibilidad por la cultura como Valladar, quien se apresuró a publicar su contenido. Tres de las misivas ofrecían datos de interés para el conocimiento de la obra del escultor, pues habían sido remitidas desde Madrid por el genovés Sebastián de Benedictis, intermediario de Mena en la corte, escribiéndole sobre diversos encargos y la demora en algunos pagos. Las otras tres cartas, en cambio, fueron enviadas desde Granada por su sobrino Fray Alonso de Mena, por su hijo Alonso y por Cristóbal Montero de Espinosa respectivamente, sobre asuntos personales del artista que también resultan de interés.

Tras su publicación en la revista La Alhambra, de ellas se hizo eco Ricardo Orueta en su antológica monografía sobre Pedro de Mena $^{2}$ y es probable que entonces fueran depositadas en el Archivo de la Casa de los Tiros de Granada, donde hoy se encuentran. Sin embargo, la carta que ahora estudiamos, enviada por Bernabé Ximénez de Illescas desde Lucena, no aparece recogida entre estas seis primeras, aunque obviamente por cronología pertenece a la serie y de hecho se encuentra custodiada junto al resto, en una caja sin numerar en el citado archivo. Fue dada a conocer por Romero Torres en 1989 en el catálogo de la exposición que, con motivo del tercer centenario de la muerte del artista, se celebró en el coro de la catedral malagueña, aunque parece que el documento había sido transcrito por Encarnación Isla Mingorance ${ }^{3}$. Una revisión del mismo, hasta ahora conocido parcialmente, nos ha

1 VALLADAR, Francisco de Paula: «Documentos y noticias de Granada. Cartas de los "Mena"». La Alhambra. Revista quincenal de Artes y Letras, 132, Granada, 30 de junio de 1903, págs. 277-280.

2 ORUETA Y DUARTE, Ricardo de: La vida y la obra de Pedro de Mena y Medrano, $1^{\text {a }}$ ed., Madrid, Junta para Ampliación de Estudios e Investigaciones Científicas del Centro de Estudios Históricos, 1914, págs. 323-325 [ed. facsímil, Málaga, Colegio de arquitectos Arte y Arquitectura - Universidad de Málaga, 1988].

3 ROMERO TORRES, José Luis: «El artista, el cliente y la obra de arte», en AA.VV.: Pedro de Mena, III centenario de su muerte 1688-1988 [cat. exp.]. Málaga, Consejería de Cultura - Junta de Andalucía, 1989, 
deparado abundantes sorpresas.

La carta, redactada en Lucena el domingo 29 de marzo de 1669 por el pintor Bernabé Ximénez de Illescas, está dirigida, con un tono encomiástico y una prosa algo farragosa, a su «señor y amigo Pedro de Mena Medrano» ${ }^{4}$. En ella se excusa el autor porque ya llevaba dos cartas sin responder, aunque extrañaba que la última de ellas se la hubieran entregado abierta. Cuenta que hasta el día en que escribe todavía no se había pasado a ver el Nazareno de Mena, debido a las desavenencias que había tenido con los comitentes, los hermanos de la Cofradía de la Pasión. Éstos habían decidido que la escultura se policromara en Málaga, lo que en la práctica privaba al pintor de los beneficios económicos que este trabajo le hubiera reportado; por otra parte, habían ignorado a Illescas en el pago a Mena de los doscientos ducados que había importado la hechura y que le fueron pagados a través de Francisco Garrafa. Pese a todo, el pintor había acudido finalmente a ver la escultura a petición de $\mathrm{D}$. Antonio de la Cueva y, según asegura, por el respeto que guardaba al escultor.

Una vez reconocida la obra, Illescas transmite a Mena el malestar de los comitentes porque, a pesar de ser una imagen «tan buena», el Nazareno no se hallaba articulado para realizar la bendición durante su estación de penitencia cada Miércoles Santo, bien porque ellos no se lo habían pedido o porque al escultor se le había olvidado. Ante este panorama, entendían los hermanos que resultaría difícil fomentar la devoción de la nueva imagen entre los fieles, habida cuenta de la existencia en la ciudad de otra imagen más antigua, de arraigo secular: un Nazareno tardogótico del Quinientos, que sí estaba preparado para realizar el simulacro de la bendición en la mañana del Viernes Santo y que entraba claramente en competencia con la nueva imagen.

Así las cosas, las cofrades no proponen, como se dijo, la devolución del Nazareno, sino sólo de sus manos, para que el escultor las acomodara en otra imagen y a cambio realizara unas nuevas, convenientemente adaptadas para la bendición, de forma que:

«la que dobla a de ser la izquierda y la que alarga la derecha, que con que este como esta la izquierda estaba dispuesta para echar la bendición cuando se ofrezca ha hacer el paso y luego volverla a poner la mano en la cruz».

Illescas solicita al escultor que tenga a bien aceptar el trueque, pues de otro modo los propietarios podrían cometer alguna barbaridad con la imagen, como la posibilidad barajada de llevarla a un ensamblador del lugar, quizás Luis Sánchez de la Cruz, para que -literalmente- le «aserrara» los dedos, algo que hasta el momento no habían realizado por consideración al pintor. Hasta aquí se vierte lo que más o menos se conocía del contenido de la carta. Sin embargo, en lo que nunca se había reparado es que en la misma se está hablando de un segundo encargo:

pág. 99, n. 2.

4 Vid. apéndice documental. 
«tanbien suplico a Vuestra Merced sea servido de un niño que se an de pedir a Vuestra Merced que haga pa don Nicolas Salvador por mano del Señor don Manuel Boço, que la haga Vuestra Merced con todo primor porque es persona que lo entiende y dibuja alguna cosa y es hombre de buen gusto y tiene dineros con que se lo pagara a Vuestra Merced cuanto quisiere. Pidiome le suplicara a Vuestra Merced esto y ansi se lo suplico a Vuestra Merced y que me mande cuanto fuere de su gusto, que siempre estare para servir a Vuestra Merced a quien Dios me guarde los años de mi deseo».

Por cierto, esta carta, además de documentar este Niño Jesús -apelando al buen gusto y entendimiento del cliente-, ofrece otros aspectos a tener en cuenta, como sus alusiones intertextuales a otras cartas que el escultor le había enviado previamente y que, aunque no se conservan, demuestran varias cosas: que ambos artistas mantuvieron una correspondencia periódica -al menos en ese año- y que, según los términos en que se expresa el pintor, es probable que mantuvieran una cierta amistad. De lo que hay que estar totalmente seguros es de la consideración artística que tenían el uno del otro, pues si Mena solicitaba al pintor que retocara sus obras -quizás los pequeños desperfectos que las esculturas podían sufrir en el viaje-, Illescas se atrevía a parangonar al escultor con el divino Miguel Ángel:

«era forçoso escribir a Vuestra Merced agradeciendole la merced que me hace en decirme que enmiende sus obras y respondo que sus obras de Vuestra Merced no necesitan de correccion de ningun artifice por grande que sea (ilegible) ni mas deva $/ v^{\circ}$ tan corto ynjenio como el mio, demas que aunque yo fuera Micaelanjelo no hallara que enmendar si no dar a Vuestra Merced infinitas gracias y alabanças por lo bien que a hecho esta Santa Ymajen».

Por último, existe también un detalle en la carta que nos introduce en la historia a un tercer protagonista. Una vez agotado el espacio del folio, continúa Illescas escribiendo en el margen hasta firmar y fechar la carta para, seguidamente, anotar: «suplico a Vuestra Merced me haga fabor de dar esta carta al señor don Juan Niño, nuestro amigo». Este Juan Niño no ha de ser otro que el pintor malagueño Juan Niño de Guevara, de quien se ha afirmado que mantuvo una relación profesional con Mena ${ }^{5}$ pero no que los tres artistas fueran amigos o, cuando menos, se conocieran. Pudiera ser que la carta le fuera entregada a Pedro de Mena a través de Niño de Guevara, porque de otro modo no se entendería esta extraña posdata.

5 Siguiendo a Llordén, se cree que el desaparecido retablo de la Virgen de los Reyes de la catedral de Málaga fue tallado por Pedro de Mena, bajo traza de Juan Niño de Guevara. Cfr. CLAVIJO GARCÍA, Agustín: Juan Niño de Guevara, pintor malagueño del siglo XVII. Málaga, Universidad, 1998, págs. 28 y 213. Sin embargo, Romero Torres cree que se trató de un concurso al que acudieron diversos artistas, como Juan Niño y Jerónimo Gómez, pues a este último también se le paga una traza, aunque finalmente Mena se hizo con el encargo. Cfr. ROMERO TORRES, José Luis: «El artista, el cliente...», pág. 110. 


\section{El agente: Bernabé Ximénez de lllescas.}

Como suele ocurrir con numerosos pintores de nuestro Siglo de Oro, la principal fuente para conocer la vida y la obra de Bernabé Ximénez de Illescas son los apuntes biográficos que sobre él nos dio Palomino en su Parnaso español pintoresco laureado. De él dice que era natural de Lucena, hijo de padres nobles y que desde sus primeros años estuvo inclinado al arte de la pintura, práctica que

«interrumpió con la afición a la milicia, en que se empleó algunos años, con más ardimiento, que fortuna. Hallándose [...] en Roma en la edad juvenil todavía, aprovechó la ocasión de cultivar su genio para la Pintura en el espacio de seis años, que estuvo en aquella ciudad; de donde vino a Lucena muy aprovechado, especialmente en la puntualidad del copiar, y en la caprichosa inventiva de los grutescos, y follajes ${ }^{6}$.

Sobre su fecha de nacimiento hasta ahora no existía certeza. Palomino no la citó y Ceán escribió que tuvo lugar en $1613^{7}$. El dato, sin embargo, ya fue tempranamente puesto en entredicho por el erudito local Fernando Ramírez de Luque en sus Tardes divertidas, asegurando que el pintor había sido bautizado el 12 de junio de 1616 en la parroquia de San Mateo de Lucena ${ }^{8}$. Es cierto que en tal día nació un Bernabé, hijo de Asensio Jiménez y Marina de Cuenca, pero no será éste el futuro pintor, pues en el Archivo Parroquial de San Mateo hemos encontrado la verdadera partida de bautismo. En realidad, Bernabé, hijo de Damián Ximénez de Illescas e Isabel de la Cruz, fue bautizado el 21 de junio de 1608 en la citada parroquia por el vicario Diego de Algar ${ }^{9}$. Fueron sus padrinos el regidor Juárez y su mujer doña Isabel, lo que avala el probable origen nobiliario de su familia como apuntó Palomino.

Su padre, natural de la localidad cordobesa de Castro del Río, se había casado con la lucentina Isabel de la Cruz el 19 de noviembre de 1598 en la parroquia de San Mateo de Lucena ${ }^{10}$. Por su parte, Bernabé Ximénez de Illescas casó a sus veinte

6 PALOMINO DE CASTRO Y VELASCO, Antonio Acisclo: El Museo Pictórico y Escala Óptica. Tomo tercero. El Parnaso español pintoresco laureado... Madrid, Lucas Antonio de Bedmar, 1715-1724 [reed. Madrid, Aguilar, 1988], págs. 321-322.

7 CEÁN BERMÚDEZ, Juan Agustín: Diccionario histórico de los más ilustres profesores de las Bellas Artes en España, t. VI. Madrid, Real Academia de San Fernando, 1800 [reed. Madrid, Reales Academias de Bellas Artes de San Fernando y de la Historia, 1965], págs. 13-14.

8 RAMÍREZ DE LUQUE, Fernando: Tardes divertidas y bien empleadas por dos amigos en tratar de la verdadera historia de su patria Lucena. Lucena, 1794-1808 [reed. Lucena, Tenllado, 1998], pág. 136.

9 Archivo Parroquial de San Mateo de Lucena [A.P.S.M.L.], Libro $16^{\circ}$ de bautismos, fol. 47: «En la bylla de Lucena en veinte y un días del mes de Junio de mil y seiscientos y ocho años yo Diego $A^{\circ}$ de Algar Vicario y cura de la iglesia Parrochial de San Matheo de esta dicha villa baptice a Bernabé hijo de Damián Ximénez y de Ysabel de la Cruz su muger fueron sus Padrinos el Regidor Juarez y doña Isabel su muger y les adverti el parentesco espiritual que contrajeron y lo firme. Diego de Algar [firmado y rubricado]».

10 A.P.S.M.L., Libro $3^{\circ}$ de desposorios, fol. 106 v": "Y a Damian Ximenez de Yllescas vezino de Castro el Rio y a Ysabel de la Cruz hija de Diego Luis de Nieba vezina de Lucena despose por palabras de presente abiendo precedido las tres municiones que el derecho manda y no abiendo enpedimento siendo testigos Bartolomé Ximenez y Andres de Nieba y Lorenço Rosales vecinos de Lucena a dezinuebe de noviembre de mil y quinientos y noventa y quatro años. Baltasar López [firmado y rubricado]». 
años con doña Clara del Castillo en $1628^{11}$ con quien al menos tuvo tres hijos: Damián $(1632)^{12}$, Isabel $(1634)^{13}$ y María Margarita (1642) $)^{14}$.

Ximénez de Illescas se perfila como una figura enigmática por las numerosas incógnitas que todavía existen sobre su vida y obra. Si atendemos a sus supuestos orígenes nobiliarios y a su faceta militar no parece que tuviera a su cargo un amplio taller, como acreditan sus escasas obras documentadas. Su presumible desahogo económico le permitiría no depender directamente de los ingresos de su actividad como pintor. A este respecto, Palomino refiere que no ejercitó mucho la pintura «porque el resto de su vida siguió con demasiada afición sus principios marciales». Sin embargo, su caso no fue el único, considerando por ejemplo el pasado militar del pintor flamenco Miguel Manrique.

Otro aspecto controvertido es su estancia romana, sobre todo si atendemos a que el paso por Italia no fue habitual entre los pintores españoles de su época, como ya señaló Pérez Sánchez ${ }^{15}$. Si, como afirma Palomino, en su juventud estuvo en Roma por tiempo de seis años, resulta difícil ajustar las fechas, habida cuenta que casó en 1628 a sus veinte años y que entre 1632 y 1634 tuvo dos hijos. Por ahora, y a falta de nuevos hallazgos documentales, existe un salto cronológico entre este último año y 1641-1642 en que se le registra un pago de «ciento y setenta y quatro reales... por raçon de un quadro que hiço para la capilla nueba del sagrario» que la Cofradía del Santísimo estaba construyendo en la parroquia de San Mateo de Monturque, lo que ha llevado a pensar en una probable participación en la decoración pictórica de la bóveda del Sancta Santorum del citado recinto ${ }^{16}$. Además, en septiembre 1642 su mujer dio a luz a su hija María Margarita, de modo que desde finales del año anterior debió estar afincado en la ciudad. Así las cosas, la única opción plausible sería ubicar su periodo romano entre $1634 / 1635$ y 1640/1641, entre sus veintiséis y treinta y dos años, puesto que adelantarlo a su casamiento (1628), cuando todavía era un adolescente, resulta muy arriesgado. Si Palomino estaba en lo cierto, parece lógico que este hipotético contacto con la Roma de Urbano VIII indudablemente debió despertar su interés por

11 A.P.S.M.L., Libro $6^{\circ}$ de desposorios, fol. 303. La referencia está tomada del índice de bautismos porque el citado libro no se conserva, lo que nos impide conocer la fecha exacta en que se casaron.

12 A.P.S.M.L., Libro $20^{\circ}$ de bautismos, fol. 321 vo: «En la ciudad de Lucena en veinte y cinco días del mes de março de mil y seiszientos y treinta y dos años yo Antonio Moyano de Argote cura de esta iglesia mayor de señor San Matheo baptice a Damian hijo de Bernabe Ximenez y doña Clara del Castillo su muger. Padrinos Joan Ximenez Dominguez y Doña Mencia de Garbez su muger advertiles el parentesco spiritual que contrajeron testigos Fernando de Leon y Joan Baptista y firme. Antonio Moyano [firmado y rubricado]».

13 A.P.S.M.L., Libro $21^{\circ}$ de bautismos, fol. 89: «En la ciudad de Lucena en diez y seis días del mes de febrero de mil y seiscientos y treinta y quatro años yo Pedro Ramirez de Arjona cura de esta iglesia parrochial de señor Sant Matheo de esta Ciudad baptice Ysabel hija de Bernabe Jimenez y de Doña Clara su muger. Padrino D. Alonso del Valle. Testigos Juan Baptista y Juan de la Cruz y lo firme. Pedro Ramírez de Arjona [firmado]».

14 A.P.S.M.L., Libro $22^{\circ}$ de bautismos, fol. 211: «En Lucena en veinte de septiembre de mil y seiscientos y quarenta y dos años yo Antonio Moyano cura de esta iglesia parrochial de señor San Mateo baptice a Maria Margarita hija de Bernave Ximenez y de Doña Clara su mujer. Padrino Damian Ximenez de Yllescas su abuelo y lo firme de que doy fe. Antonio Moyano [firmado y rubricado]».

15 PÉREZ SÁNCHEZ, Alfonso E.: Pintura barroca en España (1600-1750). Madrid, Cátedra, 1992, pág. 27.

16 GALISTEO MARTÍNEZ, José y LUQUE JIMÉNEZ, Francisco: «EI Sagrario de la Parroquia de San Mateo de Monturque, un renovado 'locus dei' para el Barroco cordobés». Boletín de Arte, 25, Málaga, 2004, págs. 287-288. 
las artes, en la década en que el barroco romano había eclosionando definitivamente, con el baldaquino de Bernini recién levantado y las propuestas pictóricas basculantes entre el clasicismo barroco de Andrea Sacchi y el lenguaje exuberante de un Pietro da Cortona. Además del importante bagaje técnico y teórico que pudo traer de esta experiencia, desde luego también debe ser valorada la ocasión como una oportunidad de excepción para hacerse con buenas estampas.

Lamentablemente resulta prácticamente imposible apreciar la huella de esta privilegiada formación romana en su obra, por inexistente o indocumentada. Por ejemplo existen algunas noticias de obras desaparecidas, como la que nos dan Orlandi y Guarienti en su Abecedario pictórico, donde dicen que en Roma se convirtió en un gran pintor de batallas y citan una batalla de Santiago «con una multitud de figuras» que hizo para el conde de Taroca en Lisboa ${ }^{17}$. También el pintor y escultor de Puente Genil, José Ruiz Rey, en su ejemplar de Palomino, que luego adquirió Ramírez de Luque, anotó junto a la biografía de Illescas que éste había pintado un gran lienzo de la Asunción que ocupaba todo el testero de la capilla de San Pedro de San Mateo de Lucena, «copiando a Rubens», que desapareció en 1788 por su mal estado según Ramírez de Luque, quien lo conoció; siguiendo la anotación de Ruiz Rey también pintó un ciclo de la vida de San Juan de Dios para el hospital de Lucena, que sin embargo ya había desaparecido en tiempos de Ramírez de Luque, probablemente tras la reforma dieciochesca ${ }^{18}$.

Tradicionalmente se le han atribuido los lienzos de los retablos colaterales y de la capilla vieja del Sagrario de la parroquia de San Mateo de Lucena, todos ellos de mitad del siglo XVII ${ }^{19}$. Sin embargo, la inexistencia de obra documentada nos impide establecer analogías con estas pinturas anónimas de discreta factura y con otras que, a falta de nuevos hallazgos, continuarán en el anonimato. Es el caso de las pinturas murales de la citada capilla sacramental, realizadas al temple hacia 1651 fundamentalmente a partir de grutescos y follajes y algunas figuras veterotestamentarias en hornacinas, que pudieran deberse a Illescas y hacer honor a su «caprichosa inventiva de grutescos y follajes» que Palomino loaba.

A pesar de esta producción perdida, se han registrado numerosas referencias de Bernabé Ximénez de Illescas actuando como pintor policromador y dorador. Además de los encargos que hasta ahora se conocían, y que luego abordaremos, ahora le documentamos dos nuevos. En 1674 se le abonaron 9.000 reales por «bruñir, blanquear y jaspear» el nuevo monumento del Jueves Santo para la parroquia de San Mateo de Lucena, que un año antes había realizado el retablista y escultor Luis Sánchez de la $\mathrm{Cruz}^{20}$, al igual que en ese mismo año recibió otros 100 reales por dorar

17 ORLANDI, Pellegrino Antonio y GUARIENTI, Pietro: Abecedario pittorico. Venecia, Giambatista Pasquali, 1753, pág. 98

18 RAMÍREZ DE LUQUE, Fernando: Tardes divertidas, pág. 136.

19 AA.VV.: Catálogo Artístico y Monumental de la Provincia de Córdoba, t. V. Córdoba, Diputación Provincial, 1987, págs. 102 y 105

20 A.P.S.M.L., Cuentas de fábrica (1666-1685), Cuentas de 1674 tomadas por D. Jerónimo Gil Guerrero, regidor y alguacil mayor, como mayordomo y obrero de las fabricas de San Mateo y Santiago, s/f. Data 37 Bruñido, blanqueado y jaspeado al monumento. «Como consta de la partida numero 43 del discargo de dicha 
las nuevas andas que para la procesión del Santítisimo Sacramento había realizado Sánchez de la $\mathrm{Cruz}^{21}$. De ambas obras, realizadas a expensas del difunto duque de Segorbe y Cardona, nada queda.

También Palomino añade que tuvo a su cargo varios discípulos, como el presbítero lucentino Leonardo Antonio Hurtado de Castro (1656-1745), quien además de pintor y poeta, fue arquitecto y hombre de cierta erudición, probable maestro de Hurtado Izquierdo ${ }^{22}$ y autor de la Capilla del Sagrario de la Parroquia de San Mateo de Lucena (1740-1772), cumbre del barroco cordobés; el otro fue el pintor malagueño Miguel Parrilla, activo en Málaga ${ }^{23}$ y luego en Sevilla, adonde fue llamado para colaborar junto con Bernardo Simón de Pineda y Pedro Roldán en el sagrario de la Cartuja de las Cuevas (1676-1678) $)^{24}$. Allí se asentó Parrilla definitivamente para asumir nuevos encargos, como el dorado, estofado y encarnado de los retablos de San José en la Casa Profesa (1679) ${ }^{25}$ y del convento de la Encarnación (1691-1693 ${ }^{26}$, dirigir la renovación del monumento de la catedral (1688-1689) ${ }^{27}$ y encarnar algunas imágenes salidas del taller de Pedro Roldán, caso de la primitiva Dolorosa de la sevillana Hermandad de la O (1678) y su Nazareno $(1685)^{28}$.

Precisamente que este pintor malagueño fuera a Lucena a aprender con él como cuenta Palomino subraya de nuevo el prestigio que tuvo Illescas entre sus contemporáneos y su constatado vínculo con la ciudad de Málaga, donde ya conocía a Mena y Niño de Guevara y donde pudo haber trabajado en algún encargo como apuntábamos al inicio. $Y$ de lo que no cabe duda es que en el tercio central del siglo XVII, el pintor tuvo que ser el artista de más reputación en Lucena, lo que avalaría su papel como intermediario en la recepción de importantes encargos escultóricos que él se ocuparía de policromar.

quenta pasada el dicho señor Duque de Cardona dio principio a que se hiciese un monumento de madera de talla el qual se fenezio y su costo se bajo en dicha partida en la forma que en ella se hizo mención y ahora pareze que para que al tiempo que se armara tuviese mas lucimiento y perfeczion se conzerto con Bernave Jimenez de Illescas Maestro pintor de esta ciudad el que lo avia de bruñir blanquear y jaspear con los colores y pintura nezessarias y reparar las rajas y demás sentimientos que la madera pudiera hazer con el trascurso del tiempo sobre lo qual se hizo asiento y zeula con ziertas condiziones favorables a la mejor disposizion y obra y perpetuidad de ella y se ajusto en nuebe mil reales toda la dicha obra aviendose hecho conforme a las dichas condiziones el qual se esta feneciendo para que sirva el Juebes Santo próximo / Venidero y por averse reconozido que la dicha es buena y conforme al ajusto se le an pagado dichos nueve mill reales de que a dado diferentes rezivos el ultimo de primero de febrero de este año de setenta y quatro y asi se vajan y por ellos». 21 Ibidem. Data 42: Gastos de cosas de madera y andas para la (ilegible). «De una peana de madera ochavada con quatro serafines para la custodia contenida en esta quenta rezivo Luis Sanchez de la Cruz escultor - 130 reales. De cinco libros de oro para el dorado - 115 reales. A Bernave Jimenez dorador del dorado - 100 reales».

22 TAYLOR, René: Arquitectura andaluza: los hermanos Sánchez de Rueda. Salamanca, Universidad, 1978, pág. 14.

23 LLORDÉN SIMÓN, Andrés (O.S.A.): Pintores y doradores malagueños. Ensayo histórico-documental (Siglos XV-XIX). Ávila, Ediciones del Real Monasterio de El Escorial, 1959, págs. 246-247.

24 CEÁN BERMÚDEZ, Juan Agustín: Diccionario histórico..., t. IV, pág. 57; BERNALES BALLESTEROS, Jorge: «El Sagrario de la Cartuja de las Cuevas». Laboratorio de Arte, 1, Sevilla, 1988, pág. 148.

25 LÓPEZ MARTÍNEZ, Celestino: Arquitectos, escultores y pintores vecinos de Sevilla [col. Notas para la Historia del Arte]. Sevilla, Rodríguez Jiménez y Cía., 1928, pág. 230.

26 LLORDÉN SIMÓN, Andrés (O.S.A.): Pintores y doradores malagueños.... pág. 248.

27 GARCÍA HERNÁNDEZ, José Antonio: «Las imágenes escultóricas del monumento de la catedral de Sevilla en la renovación de 1688-1689». Atrio, 1, Sevilla, 1989, pág. 43.

28 RODA PEÑA, José: «Los encargos escultóricos de las instituciones sevillanas durante el reinado de Carlos

II», en AA.VV.: Roldana [cat. exp.]. Madrid, Junta de Andalucía - Consejería de Cultura, 2007, pág. 89. 
Sobre la fecha de su óbito, Palomino recogió que había muerto en la villa de Andújar, «por el año de 1671, habiendo sido llamado para una obra pública, que preocupado en la muerte, no la pudo ejecutar; siendo ya su edad de cerca sesenta años». De nuevo Ramírez de Luque en sus Tardes divertidas advirtió que el dato era erróneo, dado que se registra el entierro de Bernabé Ximénez de Illescas el 31 de agosto de 1678 en la parroquia de San Bartolomé de Andújar, probablemente enfermado tras un duro y caluroso viaje desde Lucena, teniendo en cuenta que cumplía ya setenta años ${ }^{29}$.

\section{El artista: Pedro de Mena y su taller.}

Conviene recordar que el entramado clientelar de Pedro de Mena tuvo que ser bastante amplio para explicar la dispersión geográfica de buena parte de su obra que, lejos de limitarse a Granada y Málaga, se reparte por toda España e Hispanoamérica. De hecho, gracias a las cartas que antes citábamos, sabemos que hacia 1668 Sebastián de Benedictis era su intermediario en la corte, del mismo modo que hacia 1686 lo era Felipe de Zayas ${ }^{30}$.

Por otra parte, la recepción en la provincia de Córdoba de obras de Pedro de Mena fue un hecho. Además del citado Nazareno y el probable Niño para Lucena, en Cabra se conserva un San Pedro Mártir documentado en la parroquia de la Asunción ${ }^{31}$ y en la parroquia de Santiago de Montilla un San Francisco, misionero del Perú oriundo de Montilla, que le fue encargado por los marqueses de Priego en 1647 para el convento franciscano ${ }^{32}$, sin citar otras imágenes de segura atribución y los encargos que recibió para la capital. A pesar de esta presumible clientela cordobesa, conviene recordar que por entonces Pedro de Mena gozaba de un alto prestigio nacional, después de haber realizado la sillería coral de la catedral malagueña y haber probado fortuna en la corte entre 1662 y 1663. Aunque buscó, sin éxito, el título de escultor del rey, había sido nombrado maestro mayor de escultura de la catedral de Toledo y trabajaba asiduamente para importantes comitentes de la nobleza y el clero, caso del crucificado que realizó para el Príncipe Doria en Génova o las esculturas orantes de los Reyes Católicos para el cabildo de la catedral de Granada. A este factor se suma la envergadura de su taller malagueño, con un buen número de escultores a su cargo, de modo que conviene ser cautos a la hora de vincular obras con el maestro. Es cierto que existe un importante número de esculturas que llevan el sello del taller de

29 En el libro 15 de defunciones de la parroquia de San Bartolomé de Andújar, fol. 541: «Bernabé Jiménez vecino que fue de la ciudad de Lucena, maestro de la pintura, murió en esta ciudad en casa de Andrés García calle de la Plaza a esta Parroquia. Se enterró en ella el día 31 de agosto de 1678 años. No hubo bienes por haberlos enviado el difunto a dicha su tierra. Sólo supe le debían 36 reales en casa de Juan Eufrasio el pintor de la plaza Mestanza». RAMÍREZ DE LUQUE, Fernando: Tardes divertidas..., pág. 136.

30 GILA MEDINA, Lázaro: Pedro de Mena..., pág. 49.

31 ROMERO TORRES, José Luis: «El artista, el cliente...», pág. 103.

32 AA.VV.: Catálogo artístico y monumental de la provincia de Córdoba, t. VI. Córdoba, Diputación Provincial, 1993, pág. 154; GILA MEDINA, Lázaro: Pedro de Mena..., pág. 79. 
Mena, lo que no implica que siempre se diera la intervención directa del maestro en ellas, dependiendo en buena medida de la importancia de la comitencia y del precio concertado. Ahora bien, si aceptamos que contó con un amplio taller, los encargos menores no deben ser desdeñados, pues darían faena cotidiana a sus oficiales y, sobre todo, redundarían en un mayor beneficio económico del maestro, teniendo en cuenta los múltiples negocios -comercio de seda, cera o esclavos, arriendo de inmuebles...- que llevaba al margen de la propia actividad artística ${ }^{33}$.

Como demuestra la carta, se documentan al menos dos encargos a Pedro Mena para Lucena a través de Bernabé Ximénez de Illescas. Sin embargo, de nuevo nos encontramos ante la repetida tragedia de los documentos sin obras y obras sin documentos, de manera que de aquellas obras poco se sabe. El Nazareno de la Cofradía de Pasión se encuentra en paradero desconocido. La última noticia que de él tenemos es que hace unas décadas se encontraba depositado en el palacio de los marqueses de Campo de Aras en Lucena y que sus herederos lo custodian hoy en un oratorio particular de Sevilla. Sin embargo, esta imagen parece obra posterior, algo torpe y vinculable al estilo del escultor local Andrés Cordón (siglos XVIII-XIX), por lo que en nada tiene que ver con la obra de Mena. Tampoco tenemos noticia alguna de aquel Niño Jesús que Illescas le pide, ni tan siquiera del tal Nicolás Salvador que lo encarga. Sin embargo, Ramírez de Luque pudo ver a unos «Niños Jesús y San Juan» que eran «de lo mejor del mismo Mena» en casa de don Antonio de Mora, conde de Santa $\mathrm{Ana}^{34}$, que quizás guarden alguna relación con aquel, aunque nada sepamos de su paradero.

Pese a que estas dos obras documentadas no se conserven, ciertamente existen en Lucena un pequeño grupo de esculturas afines al estilo de Mena, cuya autoría conviene reconsiderar atendiendo a la presencia de Bernabé Ximénez de Illescas en la ciudad.

\section{El CLIENTE: LAS Élites locales y las cofradías.}

La ciudad de Lucena en el siglo XVII formaba parte de un territorio de señorío, perteneciente al marquesado de Comares, por entonces vinculado a la casa de Medinaceli. A la muerte en 1670 de don Joaquín de Córdoba y Aragón, VI marqués de Comares, el título pasó a manos de su hermana mayor, doña Catalina Antonia de Córdoba y Aragón, mujer desde 1651 del VIII duque de Medinaceli, el influyente Juan Francisco Tomás de la Cerda ${ }^{35}$, quien llegó a ser primer ministro de Carlos II entre 1679 y 1684 y fue padre del penúltimo virrey español de Nápoles, Luis Francisco de la Cerda y Aragón, a la sazón IX duque de Medinaceli. No obstante, con el duque en Madrid, la ciudad quedaba en manos de su representante en Lucena y los regidores

33 GILA MEDINA, Lázaro: Pedro de Mena..., págs. 52-53.

34 RAMÍREZ DE LUQUE, Fernando: Tardes divertidas..., pág. 146.

35 LÓPEZ DE CARDENAS, Fernando José: Memorias de la ciudad de Lucena y su territorio, con varias noticias de erudición pertenecientes a la Bética. Écija, Imprenta de Benito Daza, 1777, pág. 273. 
2. Pedro de Mena y taller (atribución). Sagrado Lavatorio, 1679. Ermita de Dios Padre, Lucena.

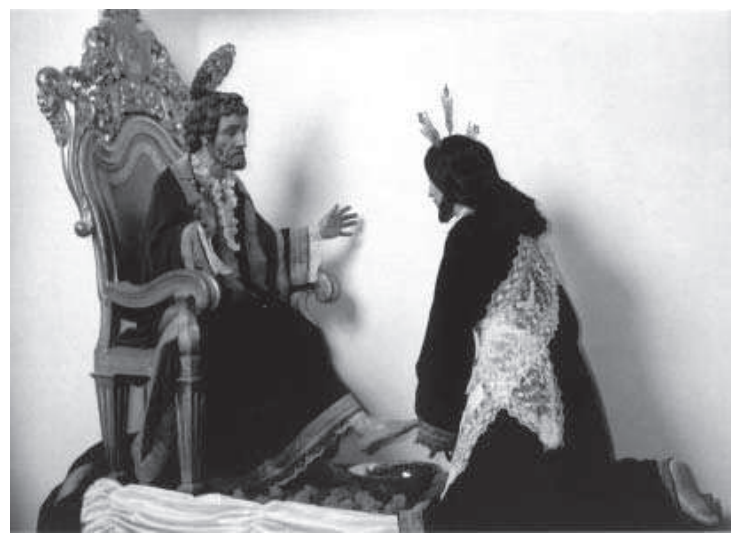

del cabildo. Precisamente son estas élites locales las que ejercían buena parte del mecenazgo artístico, pues además de alhajar sus palacios y oratorios, eran las responsables de la fundación de memorias, patronatos y capellanías en parroquias y conventos y, lo que más nos interesa para el caso, monopolizaban el gobierno de las hermandades y cofradías en un claro intento de afirmarse socialmente.

En la década de 1670, tres de las cinco cofradías penitenciales de Lucena viven un momento de esplendor artístico con la adquisición de interesantes esculturas para ser procesionadas, en un momento en que la religiosidad popular parecía ir en aumento ante la complicada situación económica y social de la España de Carlos II, agravada con la terrible epidemia de peste que llegaría en 1679. La adquisición por parte de la Cofradía de Pasión del aludido Nazareno de Mena parece que supuso un revulsivo para que otras dos cofradías decidieran ponerse al día.

Una de estas figuras de la nobleza local fue la de D. Luis de Guzmán y Soto, hermano mayor de la Cofradía de la Paz y Veracruz entre 1675-1679. A este personaje, oriundo de El Puerto de Santa María y vinculado desde antiguo al ducado de Medinaceli, una vez quedaron agregadas las casas de Comares y Medinaceli por la referida herencia, le fue confiado el título de Contador Mayor del marquesado de Comares por Juan Francisco de la Cerda. Así las cosas, por aquellos años se trasladó a Lucena para administrar los bienes y representar los intereses del duque de Medinaceli, quien además le concedió nada menos que el permiso para que él y sus sucesores fueran enterrados en la Capilla Sacramental -actual Sagrario viejo- de la parroquia mayor de San Mateo, construida en 1650 a expensas del V marqués de Comares, Luis Fernández de Córdoba y Aragón, merced a los servicios que desde hacía treinta años les venía prestando a él y a su difunto padre ${ }^{36}$.

Durante el periodo en que Luis de Guzmán fue hermano mayor, la Cofradía de

36 A.P.S.M.L., Legajo s/c y s/f, Licencia de enterramiento a favor de Don Luis de Guzmán y Soto, herederos y sucesores. 


\begin{tabular}{|c|c|}
\hline 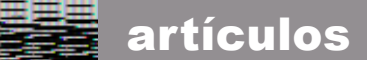 & Manuel García Luque \\
\hline
\end{tabular}

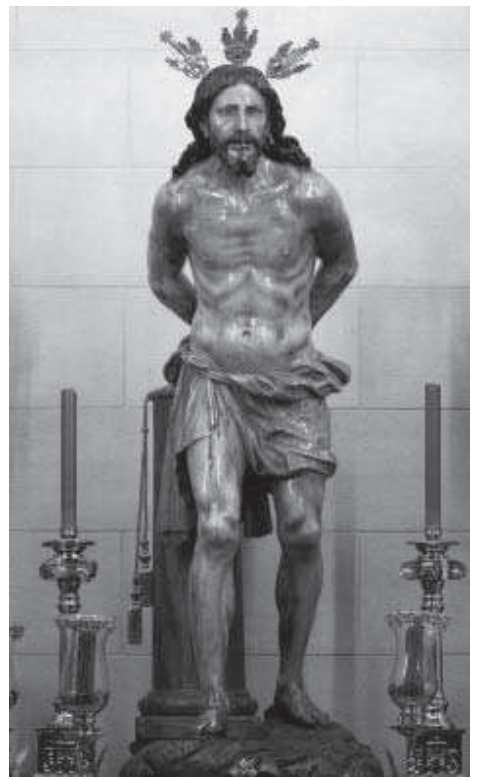

1. Pedro Roldán (escultura) y Bernabé Ximénez de Illescas (policromía). Cristo amarrado a la Columna, 1675. Iglesia parroquial de Santiago, Lucena.

significativo que también fuera policromada por Ximénez de Illescas en Lucena ${ }^{39}$.

De todo este paquete de encargos, el que más nos interesa es el del conjunto del Sagrado Lavatorio [2], probablemente salido del taller de Pedro de Mena. De los libros de cuentas se deduce la existencia ya en 1666 de un viejo paso del tema, pues en ese año de registra un pago de 200 reales al pintor Juan de Céspedes por pintar «las hechuras de Jesús y San Pedro, que es un paso que llaman del Lavatorio» ${ }^{40}$. Sin embargo, no ha de ser este conjunto el que nos ha llegado, pues existe entre la documentación

37 Ramírez de Luque ya documentó esta escultura en sus Tardes divertidas..., pág. 146, sin embargo hasta hace unas décadas no fue localizado el libro de cuentas al que hacía mención, vid. LÓPEZ SALAMANCA, Francisco: «Pedro Roldán, autor del Santo Cristo de la columna joya imaginera lucentina», Araceli, 98, Lucena, 1988. La noticia fue dada conocer a la comunidad científica por HERNÁNDEZ DÍAZ, José: «Aportaciones recientes sobre imaginería e imagineros, en el barroco sevillano». Boletín de Bellas Artes, 27, Sevilla, 1989, pág. 102.

38 La pista de Parrilla en Málaga se pierde en octubre de 1674 [LLORDÉN SIMÓN, Andrés (O.S.A.): Pintores y doradores malagueños..., pág. 247] y, aunque una crónica del siglo XVIII afirme que «fue traído de Málaga su patria» para participar en el Sagrario de la Cartuja de las Cuevas (1676) [BERNALES BALLESTEROS, Jorge: «El Sagrario...», pág. 148] es posible que ya se encontrara en Sevilla en 1675.

39 PALMA ROBLES, Luis Fernando: «De la Santa Cruz a la Santa Fe». La Voz del Sur de Córdoba, 131-132 Lucena, 1994, págs. 118-119. Esta cruz es la que actualmente forma parte del conjunto de la Alegoría de la Santa Fe, de la cofradía homónima.

40 RAMÍREZ DE LUQUE, Fernando: Tardes divertidas..., pág. 146. 
de la cofradía una escritura de donación que especifica que, durante su mandato, Luis de Guzmán lo había adquirió en Málaga en 1679, lo que por otra parte hace muy difícil que Bernabé Ximénez de Illescas, muerto en agosto de 1678 , pudiera ejercer de intermediario con el taller de Mena, como a priori pudiera pensarse. En dicha escritura, otorgada en Lucena el 10 de enero de 1701 ante el escribano Juan de Aguilar, la viuda de don Luis, doña Francisca Juana de Chavarría, hace donación del conjunto escultórico del Lavatorio y perdona una deuda a la citada Cofradía de la Veracruz a cambio de ciertos privilegios en el corral de comedias que dicha cofradía explotaba, como el uso gratuito de un camarín y un banco en la «mosquetería» para su hijo. Y lo más relevante es que en esta escritura se menciona que en un primer momento las imágenes «no fueron del contento» de don Luis, quien las devolvió a Málaga y le «hizieron otras ya viviendo en la ciudad de El Puerto de

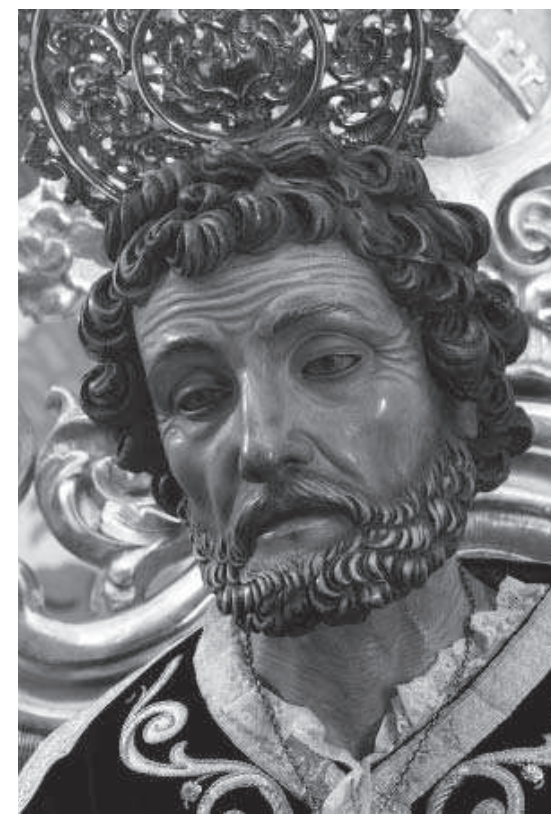

3. Pedro de Mena y taller (atribución). Sagrado Lavatorio, 1679 (detalle de San Pedro). Ermita de Dios Padre, Lucena. Santa María», que pagó a su costa y que son las que más tarde donará su viuda a la Veracruz lucentina ${ }^{41}$.

41 LÓPEZ SALAMANCA, Francisco: «De un antiguo libro de cuentas de la cofradía de la Veracruz». Torralbo, Lucena, 1988, págs. 40-42. En este artículo se cita la copia de la escritura. Nosotros hemos consultado la original que se encuentra en el Archivo Histórico Provincial de Córdoba [A.P.H.C.], Sección Protocolos Notariales de Lucena, Leg. 2569P, ff. 5-8: «En la ciudad de Lucena onze dias del mes de enero de mil setezientos y un años ante el scrivano publico de rentas y testigos infrascriptos parezieron de presente Doña Francisca Juana de Torres Ponze de Leon viuda de Don Luis de Guzman y Soto [...] tutora y cuidadora de las personas y vienes de Don Luis de Guzman y Soto [...] y dijo que por quanto el señor Don Luis de Guzman y Soto viviendo en esta ciudad con el servicio de contador mayor de este estado fue muchos años Hermano Maior de la Cofradía de la Santa Beracruz de ella estando en el ofizio de tesorero Francisco de Burgos escribano de su (ilegible) y en las quentas que el sobredicho dio de la tesoreria [...] del año pasado de mil seiszientos y setenta y nueve, fue alcanzada en dichas quentas la Cofradia con veinte $y$ un mil seiszientos y setenta y zinco reales y veinte y seis maravedis y en que final se declara que los dos mil reales de ellos era caudal del dicho tesorero y los diez y nueve mil seiszientos y setenta y zinco reales y veinte y seis maravedís caudal del dicho Don Luis de Guzman y Soto quien los avia suplido y gastado de su caudal en cuia ocasión el sobredicho Don Luis mando hazer para dicha cofradía dos hechuras en la ciudad de Malaga del Lavatorio de Jesus a Señor San Pedro y aviendolas traido de esta ciudad no fueron a contento del dicho Don Luis y las llevo Luis a dicha ciudad de Malaga y hizieron otras estando ya viviendo en la ciudad de El Puerto de Santa Maria el dicho Don Luis donde se llevaron y las pago el susodicho de su caudal y la otorgante viendo la posibilidad de dicha cofradía en darle satisfazion de su costo y cobranza del alcanze de maravedís referido [...] y siendo su voluntad deliberada es que dichas hechuras permanezcan, estén $/ 55^{\circ}$ y se conserven en la Hermita que dicha Cofradia tiene en esta dicha ciudad [...] en señal de posesion las entrego a Don Andres de Cuenca Avendaño Presvitero Hermano 


\begin{tabular}{|c|c|}
\hline 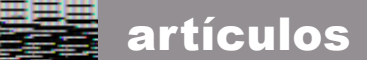 & Manuel García Luque \\
\hline
\end{tabular}

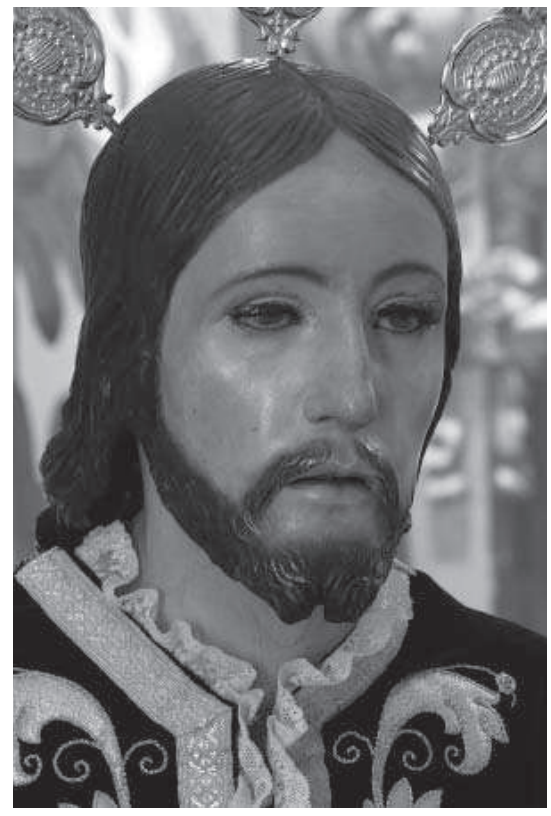

4. Pedro de Mena y taller (atribución). Sagrado Lavatorio, 1679 (detalle de Jesús). Ermita de Dios Padre, Lucena.

El Sagrado Lavatorio es ciertamente una iconografía poco frecuente, con más precedentes pictóricos que escultóricos, muy pocos en el caso de la escultura procesional. Sin embargo, su presencia se justifica en una cofradía como la de la Veracruz, quizás la más teatralizada de las cofradías pasionistas de Lucena, que sacaba en procesión pasos tan extraños como la Alegoría del Concilio de Trento o, a partir del XIX, la de la Santa Fe, y que explotaba el citado corral de comedias. El tema del Lavatorio está tomado del Evangelio de Juan (13, 1-20) y hace alusión al momento en que Cristo lavó los pies de sus apóstoles antes de la Cena. En Oriente era costumbre que los esclavos lavaran los pies de los invitados, de modo que con este gesto de servidumbre el Cristianismo reafirma la humildad de Cristo y justifica el bautismo de los apóstoles, previo a recibir la Sagrada Forma. Además el asunto contaba con referencias en el Antiguo Testamento (los tres ángeles que se aparecieron a Abraham) y la tradición hebrea (las abluciones que practicaban los sacerdotes judíos en el «Mar de Bronce» antes de entrar al templo de Salomón) que apuntaban a la dimensión purificadora del agua. Y para los teólogos medievales este episodio quedaba ligado al sacramento de la Penitencia, del mismo modo que la Última Cena a la Eucaristía, de tal suerte que fue incorporado a la liturgia del Jueves Santo, cuando el obispo solía arrodillarse para lavar los pies a doce pobres ${ }^{42}$.

Mayor y demas Hermanos de dicha Cofradia que se declararon en esta escriptura la qual dicha donazion haze con las condiziones siguientes: [...] la otorgante haze a la dicha Cofradia la dicha donazion de las dichas dos hechuras y remisión y perdón de dicha cantidad de maravedís del alcanze referido [...] y en agradecimiento de lo relazionado en nombre de dicha cofradía dan y señalan a la dicha Doña Francisca Juana de Torres Ponze de Leon para la susodicha y para sus Herederos ${ }^{7}$ y suzesores el uso del quarto camarin de las casas de Comedias de esta ciudad que son de dicha Cofradia que es al lado yzquierdo del de la ciudad para en todas las ocasiones que aya compañía de Comedias y se representen en esta ciudad y al dicho Don Luis de Guzman y Torres hijo de la dicha Doña Francisca Juana de Torres dan el uso del sitio donde se pone un banco de quatro varas de largo desde la esquina del tablado de dichas casas (ilegible) al camarin de su Excelentísima el Duque mi señor en el sitio que llaman mosquetería (ilegible) por lo uno ni otro los susodichos pagaran ni contribuyan cosa alguna a dicha cofradía ezepto las entradas en las puertas como es costumbre que estas (ilegible) pagar y satisfacer [...]».

42 RÉAU, Louis: Iconografía del Arte Cristiano, t. I, vol. II. Barcelona, Del Serbal, 1996, págs. 422-423. 
El salto de esta iconografía a la escultura procesional parece que se dio en Málaga, cuando en 1635 el escultor Pedro Fernández de Mora realizó para la Hermandad de la Pura y Limpia Concepción -tan afín a estas iconografías curiosas- una imagen de Cristo arrodillado ante San Pedro, lavando sus pies ${ }^{43}$. Como ocurrió con buena parte del sur de Córdoba, en Lucena las influencias malagueñas estuvieron muy presentes y en el mismo siglo la Hermandad de la Veracruz ya contaba con un paso similar, al menos desde 1666. Por tanto, a la hora de realizar el encargo, don Luis contaba con un referente lucentino del mismo modo que Pedro de Mena contaba con uno malagueño.

La atribución de este conjunto del Lavatorio a Pedro de Mena fue tempranamente formulada por Ramírez de Luque ${ }^{44}$ y viene siendo recogida en los últimos años por la crítica $^{45}$. El grupo hoy forma parte de una cofradía moderna, la de la Santa Fe, y se encuentra en la ermita de Dios Padre de Lucena. Está formado por las imágenes de vestir de Pedro [3] y Jesús, ambas de tamaño natural, con cabeza, manos y pies de talla. El pontífice aparece sentado sobre la cátedra, con los brazos abiertos en ademán de sorpresa. Realmente interesante es el tratamiento de la cabeza, lo más logrado del conjunto y posiblemente con intervención directa de Mena. Es interesante la interpretación que hace Mena de la ancianidad de Pedro, con barba poblada y cabellera de esmerados rizos. Sus ojos almendrados de cristal y el detalle de las arrugas de la frente y el cuello recuerdan no poco el estilo del maestro y su virtuosismo en el manejo de las gubias. Por otra parte, este San Pedro supone un elocuente testimonio de la evolución del arte de Pedro de Mena, entre aquel estilo de juventud que manejaba en el San Pedro de San Antón de Granada (ca. 1646-1652) ${ }^{46}$ y el estilo maduro con que trabaja ahora en éste de Lucena, aun laborando sobre el mismo tipo.

Mucho más sumaria es la talla del Cristo [4], que aparece arrodillado como es característico en la iconografía occidental, pese a que Trento la considerase una pose indecorosa para representar al Redentor ${ }^{47}$. Desde Ramírez de Luque en adelante, cuantos se han acercado a la obra han señalado la menor calidad de esta imagen, como obra de taller, barajando los nombres de Jerónimo Gómez y Miguel Zayas como probables autores. Sin embargo, resulta difícil apuntar nombres, habida cuenta de las escasas noticias que todavía tenemos del taller de Mena. La atribución al escultor

43 SÁNCHEZ LÓPEZ, Juan Antonio: El alma de la madera. Cinco siglos de iconografía y escultura procesional en Málaga. Málaga, Hermandad de la Amargura, 1996, págs. 110-111.

44 RAMÍREZ DE LUQUE, Fernando: Tardes divertidas..., pág. 146.

45 El grupo no aparece recogido en el en AA.VV.: Catálogo Artístico y Monumental..., t. V, quizás porque aún estuviera en oratorio particular. Sí aparece recogido en VILLAR MOVELLÁN, Alberto: Guía artística de la Provincia de Córdoba. Córdoba: Universidad de Córdoba - Grupo Arca, 1995, pág. 605 [«se ha puesto en relación con el círculo de Pedro de Mena»]; VILLAR MOVELLÁN, Alberto, DABRIO GONZÁLEZ, María y RAYA RAYA, María Ángeles: Guía artística de Córdoba y su provincia. Sevilla-Córdoba, Fundación José Manuel Lara - Ayuntamiento de Córdoba, 2005, pág. 497 [«la de San Pedro del Lavatorio es del taller de Pedro de Mena y Medrano»]; ROMERO TORRES, José Luis: «La imaginería de Málaga, Córdoba y Jaén o la búsqueda de una personalidad artística», en FERNÁNDEZ DE PAZ, Esther (coord.): Artes y Artesanías de la Semana Santa andaluza, t. II. Sevilla, Tartessos, 2004, pág. 433.

46 Este San Pedro hace pareja con un San Pablo, ambos hoy en el convento de San Antón pero procedentes del convento de capuchinas de San Antonio Abad, donde las conoció Ceán Bermúdez. GILA MEDINA, Lázaro. Pedro de Mena..., pág. 80.

47 RÉAU, Louis: Iconografía..., t. I, vol. II, págs. 422-423. 
Jerónimo Gómez de Hermosilla (1630-1719) es poco factible pues, a pesar de que se impregnó del estilo de Mena, no formó parte de su taller, mientras que otro tanto ocurre con Miguel Félix de Zayas (1661-1713) que, aunque sí formó parte del taller, al momento de su realización era demasiado joven como para considerar una participación de importancia. La cabeza de Cristo sigue claramente los modelos menoides, pero tanto el pelo como la barba están bastante simplificados, acusando el peso de colaboradores. No en balde, este tipo de imágenes, concebidas para ser vestidas, resultaban menos atractivas para el trabajo escultórico y, sobre todo, más baratas.

El otro gran mecenas de este momento fue Jerónimo Gil Guerrero. Hijo de don Jerónimo Gil Guerrero, familiar y Alguacil Mayor del Santo Oficio, y de doña Catalina Hurtado de Navas, alcanzó como su padre el Alguacilazgo Mayor de Lucena, y posteriormente los cargos de Alférez Mayor, Teniente de Corregidor y Contador Mayor del Duque de Medinaceli a partir de $1689^{48}$. Lo que más nos interesa de su figura es el mecenazgo que ejerció desde las distintas cofradías de las que fue hermano mayor: de la Archicofradía del Carmen entre 1653 y 1676, de la Veracruz hacia $1684^{49}$ y finalmente de la de Ntra. Sra. de Araceli. Entre las empresas artísticas que impulsó cabe citar las obras del camarín y el retablo del santuario de Araceli, que se comenzaron bajo su mandato, o la iniciativa para fundar en 1686 un convento de frailes mínimos de San Francisco de Paula, bajo el patrocinio del cabildo municipal, en acción de gracias por el fin de la epidemia de peste ${ }^{50}$.

De todas ellas, destaca su período al frente de la Archicofradía del Carmen, que regentó durante varias décadas, y la vinculación que tuvo con el convento de carmelitas descalzos, donde mandó ser enterrado con el hábito de San Francisco según su testamento ${ }^{51}$. Precisamente con Jerónimo Gil Guerrero a la cabeza, esta cofradía carmelitana acordó en un cabildo el 24 de abril de 1672 que:

«por quanto la insignia principal desta Hermandad de Jesús Preso a que tienen con la incuria del tiempo algo deslucida es necesario renovarla para que sea de mano de un artífize de mucho primor, para que permanezca porque se va mirando a la perpetuidad, acordaron se haga una hechura de Pedro de Mena $\mathrm{u}$ otro escultor que les guste en la ciencia» ${ }^{52}$

Para tal efecto se hizo una primera colecta entre los hermanos presentes en

48 BLANCAS, Demetrio: «Dos cofrades de la Vera-Cruz: D. Jerónimo Gil Guerrero y D. Enrique de Guzmán El Bueno». Torralbo, Lucena, 1988, págs. 46-48; LÓPEZ SALAMANCA, Francisco. «Notas para la historia de la Venerable Archicofradía del Carmen (V)». Carmelo de Pasión, 9, Lucena, 2003, págs. 4-5. Mi gratitud a José Manuel Valle Porras por haberme facilitado su trabajo sobre los regidores de Lucena, elaborado a partir de las actas del cabildo municipal, que espera publicar en breve.

49 LÓPEZ SALAMANCA, Francisco: «De un antiguo libro...», págs. 40-42.

50 LÓPEZ DE CARDENAS, Fernando José: Memorias de la ciudad de Lucena..., pág. 275.

51 SERRANO TENLLADO, María Araceli: El poder socioeconómico y político de una élite local. Los Regidores de Lucena en la segunda mitad del Siglo XVII. Córdoba, Universidad de Córdoba - Cajasur, 2004, pág. 615.

52 LÓPEZ SALAMANCA, Francisco: «Notas para la historia de la Venerable Archicofradía del Carmen (III)». Carmelo de Pasión, 6, Lucena, 2000, pág. 11. De la noticia también se hizo eco RODRÍGUEZ DE MILLÁN FERNÁNDEZ, José: "Orígenes de la Semana Santa: sus inicios en Lucena», en RODRÍGUEZ DE MILLÁN FERNÁNDEZ, José y LÓPEZ SALAMANCA, Francisco: Orígenes de la Semana Santa: sus inicios en Lucena. La Archicofradía de Jesús Nazareno: cuatrocientos años de historia. Lucena, Tenllado, 2000, pág. 97. 
el cabildo, que tan sólo ascendió 1.095 reales de manera que se instaba a recoger las limosnas de los hermanos ausentes. Finalmente acabó adquiriéndose una imagen del Preso, además de un Jesús de la Humildad y una Dolorosa que en pocos años comienzan a ser citados en los cabildos. Este Preso formó parte de la archicofradía hasta 1764 , cuando la corporación perdió su propiedad en un pleito contra sus cuadrilleros, la familia Curado, en cuya casa se custodiaba todo el año. En efecto, don Bartolomé Curado y Tello se negó, a la muerte de su padre, a ceder el Preso para la procesión, pese a que la archicofradía poseía escritura de propiedad de la imagen. Para no dilatar el pleito, la archicofradía tuvo que reconocer la propiedad de la imagen a la familia a cambio de que la cedieran anualmente para Semana Santa ${ }^{53}$. Durante los primeros años tuvo que ser así pues en 1771 se vuelve a citar un Jesús Preso en la procesión ${ }^{54}$. Sin embargo, andando en el tiempo la situación tuvo que hacerse

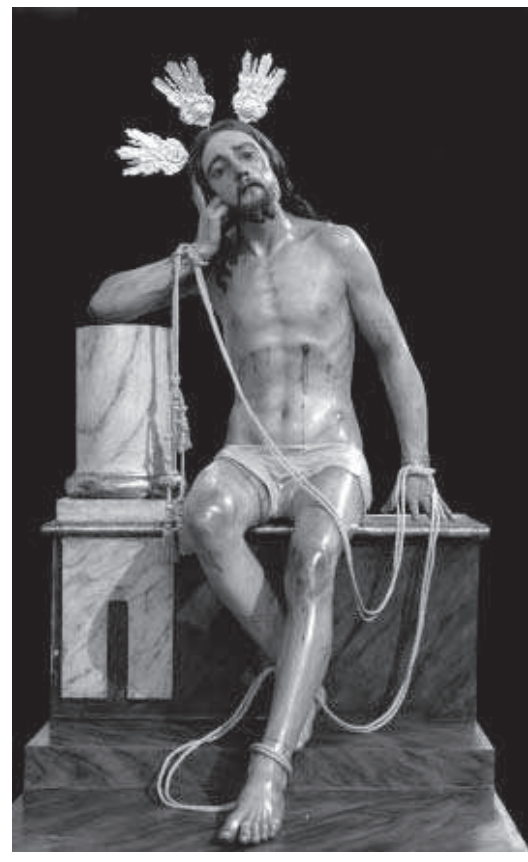

5. Pedro de Mena y taller (atribución). Jesús de la Humildad, ca. 1673-1676. Iglesia parroquial de Ntra. Sra. del Carmen, Lucena. insostenible, hasta el punto en que la archicofradía acabó declinando su interés por él y adquirió una nueva imagen, zanjando así el asunto y perdiéndose el rastro de la talla. De ahí que no podamos conocer si finalmente aquella talla del Preso que se realizó en tiempos de don Jerónimo Gil Guerrero fue encargada a Pedro de Mena, como era deseo de la hermandad y como queda expresado en los documentos.

Sin embargo, sí nos interesan las otras dos imágenes que fueron adquiridas entonces. Por lo que respecta a Jesús de la Humildad, en aquel cabildo de 1672 no se habla de su encargo aunque es muy probable que se realizara durante el periodo en que don Jerónimo Gil Guerrero estuvo al frente de la corporación, es decir, hasta el 20 de diciembre de 1676. En aquel año dimitía tras veintiún años de ejercicio y

53 Ibidem, pág. 98. Un conflicto similar ocurrió cuatro años después entre el «Hospitalico» y la Archicofradía sobre la propiedad del conjunto de la Entrada en Jerusalén, la «Pollinita». Vid. GARCíA LUQUE, Manuel y GUERRERO CABRERA, Manuel: «El conjunto escultórico de la "Pollinita" de Lucena, obra de Diego Márquez Vega y Luis Tibao: Notas de historia, arte y literatura», en Actas del I Congreso Andaluz de Patrimonio Histórico. La escultura barroca andaluza en el siglo XVIII. En prensa.

54 El paso fue acompañado en 1771 por la Archicofradía de Pasión. Cfr. LÓPEZ SALAMANCA, Francisco: "La Archicofradía de Ntro. Padre Jesús Nazareno: cuatrocientos años de historia». En: RODRÍGUEZ DE MILLÁN FERNÁNDEZ, José y LÓPEZ SALAMANCA, Francisco: Orígenes de la Semana Santa..., pág. 223. 


\begin{tabular}{|c|c|}
\hline 理 & Manuel García Luque \\
\hline
\end{tabular}

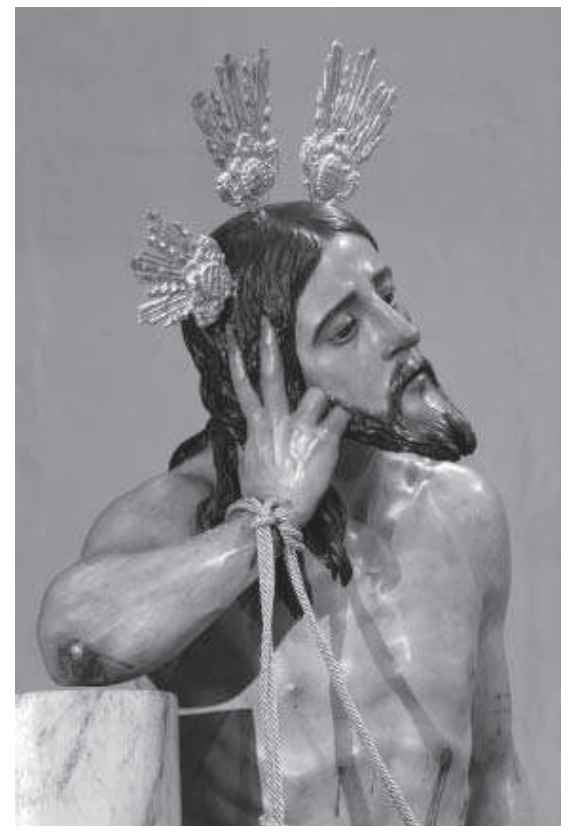

6. Pedro de Mena y taller (atribución). Jesús de la Humildad (detalle), ca. 1673-1676. Iglesia parroquial de Ntra. Sra. del Carmen, Lucena.

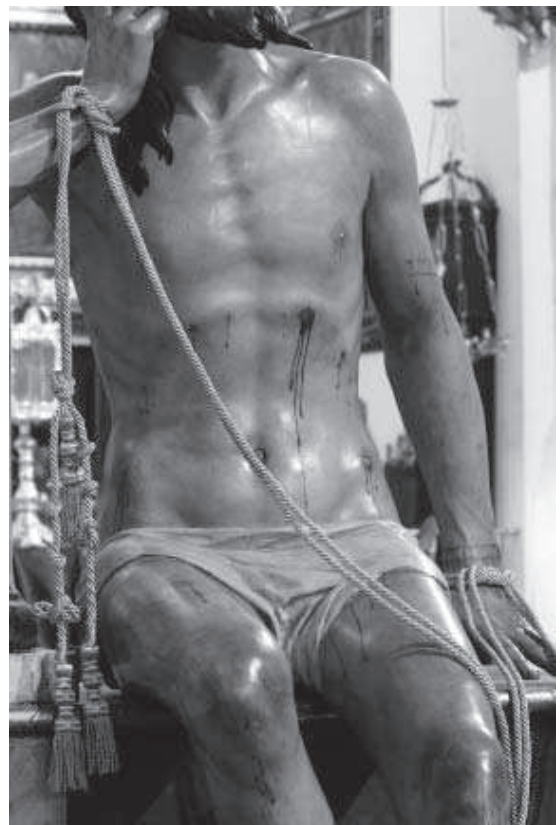

7. Pedro de Mena y taller (atribución). Jesús de la Humildad (detalle), ca. 1673-1676. Iglesia parroquial de Ntra. Sra. del Carmen, Lucena.

proponía como sustituto a don Juan Cortés Hurtado ${ }^{55}$, abogado de los Reales Consejos y ministro del Santo Oficio de la Inquisición, que sólo estuvo dos años de hermano mayor para ser relevado de nuevo por Jerónimo Gil, debido a las terribles circunstancias del momento, tras el azote de peste que sacudió el sur peninsular entre 1679 y 1680 y del que precisamente Pedro de Mena salió afectado. La gravedad de la situación obligó a la suspensión de algunas procesiones en la Semana Santa de 1680, como recoge el testimonio de dos vecinos de Rute, que el 15 de abril de aquel fatídico año, Martes Santo, visitaron la ciudad, donde "olía a ropa quemada» y toda la gente «estaba recogida en sus casas y todos mui compungidos y temerosos de la mucha gente que se moría», tanto así que aquel día se había suspendido la procesión «de la umildad de Christo del Combento del Carmen» ${ }^{56}$.

55 RODRÍGUEZ DE MILLÁN FERNÁNDEZ, José. «Orígenes de la Semana Santa...», pág. 100.

56 El documento, sin catalogar y sin foliar, se encuentra en el Archivo Municipal de Rute. Transcrito por García Jiménez, se publicó en AA.VV.: Textos histórico-geográficos de Córdoba y su provincia. Córdoba, Diputación, 1988, pág. 350. Cit. en PALMA ROBLES, Luisfernando. Cabañuelas de Pasión. La Semana Santa de Lucena: Entre la realidad y el deseo. Lucena, Delegación de Publicaciones del Ayuntamiento, 2002. Mi agradecimiento a Fernando Moreno y Luisfernando Palma por facilitarme la noticia. 
En sentido estricto, pues, habría que datar la imagen entre 1672 y 1680 , aunque conociendo las importantes adquisiciones que hizo Luis de Guzmán para la Veracruz hacia 1675, que Jerónimo Gil Guerrero dejó de ser hermano mayor a finales de 1676 y que Bernabé Jiménez de lllescas murió en 1678, se podría estrechar el cerco y afinar su datación entre 1673 y 1676 . Es más, si para 1680 no pudo procesionar la imagen, sugiere que anteriormente sí lo había hecho, lo suficiente al menos como para designar a toda la procesión de la archicofradía.

Resulta sorprendente que todavía hoy no se haya agregado al catálogo de Pedro de Mena la soberbia talla del Cristo de la Humildad [5], que proclama a gritos su paternidad. La atribución más antigua la dio Fernando Ramírez de Luque, quien dice que el Cristo y la Dolorosa fueron realizados en 1674, aunque por unos desconocidos

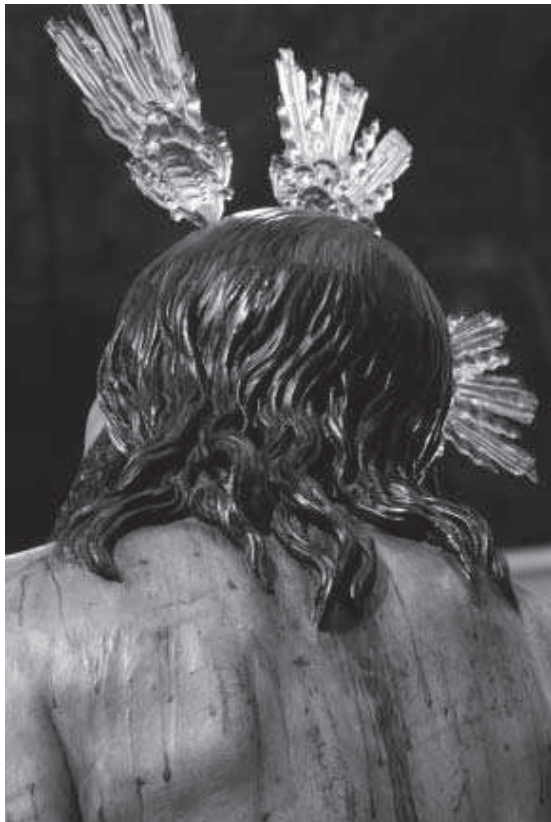

8. Pedro de Mena y taller (atribución). Jesús de la Humildad (detalle), ca. 1673-1676. Iglesia parroquial de Ntra. Sra. del Carmen, Lucena. "Ahumada granadinos»" ${ }^{57}$. En las últimas décadas surgió la atribución a Mena desde publicaciones de ámbito local, hasta que últimamente parece que poco a poco se viene aceptando por la crítica especializada ${ }^{58}$.

Entre los argumentos a favor de la atribución, además de la presencia en la ciudad de Illescas -a quien don Jerónimo conoció personalmente como mayordomo de la fábrica de San Mateo durante la fabricación del monumento ${ }^{59}$ - y el deseo de la hermandad de encargar otra imagen a Pedro de Mena, hay que apelar a la imagen

57 RAMÍREZ DE LUQUE, Fernando: Tardes divertidas..., pág. 146.

58 Es sorprendente que la talla fuera omitida en AA.VV.: Catálogo Artístico y Monumental..., t. V. Sin embargo, en los últimos años se le viene prestando mayor atención, vid. VILLAR MOVELLAN, Alberto: Guía artística de la Provincia.... pág. 615; ROMERO TORRES, José Luis y TORREJÓN DÍAZ, Antonio: «La imaginería procesional en el contexto de la producción escultórica andaluza», en FERNÁNDEZ DE PAZ, Esther (coord.): Artes y Artesanías de la Semana Santa andaluza, t. II. Sevilla, Tartessos, 2004, pág. 104; ROMERO TORRES, José Luis: "La imaginería de Málaga ...», pág. 433: TORREJÓN DÍAZ, Antonio y ROMERO TORRES, José Luis: «EI conocimiento de la escultura pasionista procesional en el contexto de la plástica andaluza», en FERNÁNDEZ DE PAZ, Esther (coord.): Artes y artesanías de la Semana Santa andaluza, t. III. Sevilla, Tartessos, 2004, pág. 311; VILLAR MOVELLÁN, Alberto, DABRIO GONZÁLEZ, María y RAYA RAYA, María Ángeles: Guía artística de Córdoba..., pág. 493; CRUZ CABRERA, José Policarpo: «La escultura barroca granadina. El oficio artístico al servicio de la espiritualidad», en AA.VV.: Antigüedad y excelencias [cat. exp.]. Bilbao, Junta de Andalucía Consejería de Cultura, 2007, pág. 127.

59 Ver nota 19. 
misma, de novedosa iconografía y talla completa. No sería descabellado pensar que Mena hubiera tenido un empeño más personal en hacerse cargo de una imagen de tales características, teniendo en cuenta las escasas ocasiones en que el artista español del Siglo de Oro podía afrontar el desnudo, en una plástica dominada por el tema religioso. Además, la fiebre por renovar los titulares había cundido entre las cofradías lucentinas hacia 1675 con adquisiciones de la calidad del Cristo a la Columna de Roldán, que a todas luces supuso un revulsivo para realizar nuevos encargos. Resulta evidente que Bernabé era el primer interesado en la afluencia de este tipo de esculturas a Lucena, puesto que con ellas conseguía el beneficio de los gastos de su encarnadura.

La escultura está realizada en madera policromada, con unas dimensiones cercanas al natural. Cristo, de tipo enjuto, asienta sobre una hipotética gradería del escenario de la flagelación, realizada en madera que imita jaspeado. Una media columna de orden toscano sirve de apoyo a su brazo derecho y un descanso para la cabeza, entre cuyo pelo se hunden los dedos [6]. Su excelente estudio anatómico avala la intervención de un artista maduro, especialmente palpable en la rotundidad del dibujo y en el tratamiento de la caja torácica, de afortunada conjunción entre el suave modelado y las calidades casi táctiles que permiten adivinar su estructura ósea [7]; sin embargo, mucho más sencillo es el tratamiento de las piernas, que recuerdan las del Cristo del Perdón de la catedral malagueña, por probable participación de taller. El sereno naturalismo con el que está interpretado el desnudo, con el complemento verista de los ojos de cristal, aparece ciertamente matizado por el aplomo clásico con que asienta la figura y su carácter apolíneo, apenas perturbado por escasos signos de maltrato físico, que parecen no hallar lugar en esta imagen sublimada, «resumen doloroso de toda la Pasión» a decir de Mâle ${ }^{60}$. No deja de ser paradójica la conjunción del carácter intimista y de contemplación cercana, inherente a los bustos de Mena y de la escuela granadina, con las necesidades rituales de la escultura procesional, que obligan a valorar la escultura en todos sus perfiles.

La figura juega con el elegante cruce de sus piernas para dinamizar en cierto modo una composición eminentemente estática, al mismo tiempo que con ellas consigue cerrar la composición en huso, acudiendo a un recurso de ascendencia canesca. Realmente interesante resulta el exquisito tratamiento del cabello, trabajado en pequeños mechones de talla menuda y profunda, que dan la sensación de pelo mojado [8]. Con todo, quizás sea su rostro la prueba más rotunda de su filiación con el maestro: nariz afilada, ojos de cristal, dientes tallados y barba bífida. Sin embargo, juegan en su contra los numerosos repintes ${ }^{61}$, de tonos muy tostados que nos lo alejan de las suaves policromías de Mena y que están ocultando, sobre todo en el pelo, el brillante acabado del modelado y sus minuciosos detalles. Tampoco hay que olvidar que

60 MÂLE, Émile: L'art religieux de la fin du Moyen Âge en France: étude sur l'iconographie du Moyen Âge et sur ses sources d'inspiration. Paris, Armand Colin, 1968, pág. 94.

61 Por ejemplo, recibió algunos retoques en la policromía en 2000 por Antonio Ortega. En aquella ocasión se situaron unas bandas de goma entre el Cristo y la peana para menguar las vibraciones pero empobreciendo la visión del conjunto, al separar considerablemente la imagen de la peana de suerte que la mano y el brazo ahora apoyan en el aire. 
quizás la policromía original no fuera del taller de Mena sino del pintor Illescas.

Con todo, este Cristo de la Humildad presenta un gran parentesco con algunas obras conocidas de Mena, especialmente con sus bustos de Ecce Homo, sobre todo con el conservado en Budia. Resulta interesante el tratamiento del perizoma, muy simplificado y pegado a la anatomía, de tipo triangular y resuelto en pocos golpes de gubia, a la manera de algunos crucificados de Mena, caso del Cristo del Perdón de la catedral de Málaga, el que porta su Magdalena penitente o el recientemente atribuido de la parroquia de la Asunción de Cabra y que no demuestran sino la deuda que Mena contrajo con los modelos de su maestro Alonso Cano. Esta manera de resolver el paño de pureza había sido tempranamente empleada por el Racionero en Sevilla (Cristo a la columna del retablo de la Campana) y encuentra un excepcional exponente en el Cristo a la Columna del Museo Nacional Rumano de Bucarest (ca. 1650).

Existe, también, otra nota canesca en este Cristo que demuestra el indudable sello del taller Mena. Se trata de las dos tarjas o placas recortadas que, frontal y lateralmente, aparecen bajo la media columna. Este motivo geométrico, que encuentra su origen en los diseños arquitectónicos de Alonso Cano, fue muy recurrente para los seguidores del maestro, tanto en obras de arquitectura como, en el caso de Pedro de Mena, en las peanas de sus esculturas. Además, es una placa que, por otra parte, en la década de los setenta parece tornarse bífida, con un entrante que perfora su centro: justo el tipo de placa que Mena comenzaba a utilizar por aquel entonces en las peanas de sus esculturas, como demuestran el San Juan Bautista Niño del Museo de Bellas Artes de Sevilla (1674), el San José (1674) y la Inmaculada (1675) de la iglesia de San Nicolás de Murcia, la Santa Clara (1675) de las Descalzas Reales de Madrid o el pequeño Cristo atado a la Columna de la colección Krauel, de la misma década. Y, es más, precisamente Mena la está utilizando en uno de sus dos dibujos autógrafos conservados: el que realizó para la escultura orante del rey Fernando el Católico, destinada a la capilla mayor de la Catedral de Granada, que le fue enviado al cabildo granadino desde Málaga y que ha aparecido en la Universidad de Leiden (Holanda) ${ }^{62}$ [9]. Así, tanto las esculturas como el dibujo, con toda seguridad de 1675, coinciden con la cronología propuesta para este Cristo.

El tema representado encuentra un precedente en las representaciones paleocristianas del anciano $\mathrm{Job}^{63}$, aunque hasta el siglo XIV no surgió la iconografía del Cristo sentado sobre una roca, esperando en el monte Calvario el suplicio de la crucifixión, que en el mundo hispano suele conocerse como Jesús de la Humildad y Paciencia ${ }^{64}$. Sin embargo, fueron la renovación espiritual que sacudió la Europa católica en los siglos XVI y XVII y el destacado papel de la mística los que propiciaron la creación de nuevas iconografías barrocas, por influencia en parte de la «composición de lugar» ignaciana y los escritos místicos, que fomentaron una narración más prolija y pormenorizada de la Pasión de Cristo, completando en lo posible toda la secuencia

62 El mismo fue dado a conocer por Sandra Tatsakis en 2003. GILA MEDINA, Lázaro: Pedro de Mena, pág 160, n. 208.

63 RÉAU, Louis: Iconografía del Arte Cristiano, t. II, vol. II. Barcelona, Del Serbal, 1996, págs. 469-471.

64 RÉAU, Louis: Iconografía del Arte Cristiano, t. I, vol. II. Barcelona, Del Serbal, 1996, pág. 488. 


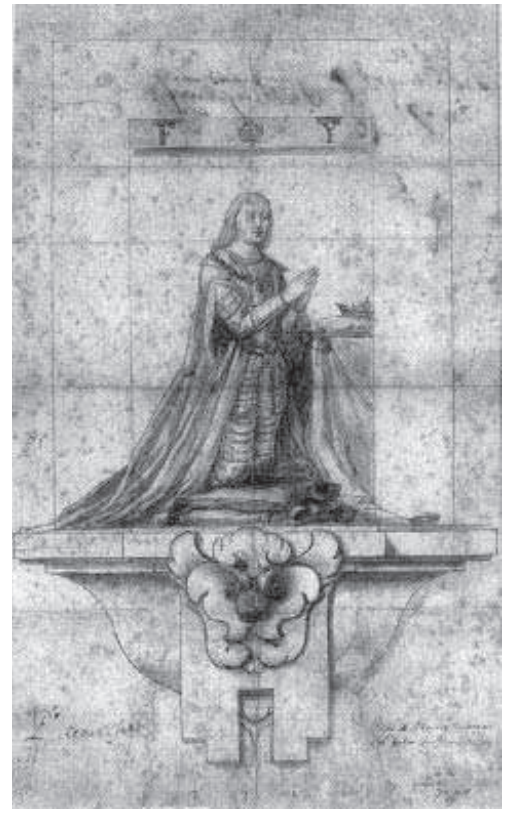

9. Pedro de Mena. Boceto de Fernando el Católico, ca. 1675. Col. Universidad de Leiden, Holanda. temporal y subsanando algunas lagunas de los Evangelios. Por eso no es difícil entender que de un episodio como la Flagelación -con tanta difusión, por cierto, en una época en que proliferaban las procesiones de disciplinantes- surgieran algunas variantes iconográficas que inciden en el carácter macabro de la escena e intentan igualmente humanizar a Cristo, siempre con el fin de conmover los afectos del fiel. Es el caso del Cristo recogiendo sus vestiduras, con excelentes ejemplos pictóricos en la obra de Cano y Murillo. Igualmente nacieron otras iconografías como la del Cristo a la Columna asistido por ángeles o ésta que nos ocupa, que no es más que una hibridación entre el Cristo pensativo y flagelado, trasladando el momento de la meditación de Cristo al instante inmediato a la flagelación, justo antes de volver ante Pilatos.

Mucho se ha insistido sobre la influencia de Durero en la difusión de esta iconografía. Es cierto que para el tema, más frecuente, de Cristo sentado en el Calvario, el frontispicio de su Pequeña Pasión (1511) fue una referencia obligada, del mismo modo que otro tanto debieron influir las numerosas estampas de la Melancolía, que solían representar a un afligido Saturno. Sin embargo, para la variante de la flagelación, aunque es cierto que se pudieron tomar algunos elementos del frontispicio de la Gran Pasión (1510) de Durero -donde el Cristo orante, coronado de espinas, no está en el Calvario sino sentado sobre un sillar de piedra-, con total seguridad debió existir otra fuente grabada que creemos sirvió de modelo para algunas esculturas y pinturas que parten de un tronco común. El grabado en cuestión debe representar a un Cristo taciturno, sentado en alguna grada, con las piernas cruzadas y el brazo derecho apoyado sobre una columna, apoyando la cabeza en su mano, con los dedos índice y corazón extendidos. Esto explicaría por qué dos imágenes de factura tan dispar y lejanas entre sí como el Jesús de la Humildad de Lucena y el de la iglesia de la Santísima Trinidad de Cuba, siguen los mismos patrones de composición, idénticos a los que un artista anónimo está esbozando en el dibujo Cristo tras la flagelación del Museo del Prado que se creyó de Cano ${ }^{65}[10]$, en el que se rastrean los mismos componentes: la presencia

65 AA.VV.: Alonso Cano. Espiritualidad y modernidad artística [cat. exp.]. Sevilla, Junta de Andalucía Consejería de Cultura, 2001, pág. 304. 
de la columna baja sobre la que apoya el brazo derecho, los escalones, la pierna izquierda cruzada sobre la derecha y la cabeza apoyada en su mano. Lógicamente, la fidelidad al modelo quedaría sujeta al criterio del artista, de manera que el detalle de los dedos también se registra en imágenes sentadas sobre una peña, como en Granada ocurre con el pequeño Cristo de Puerta Real -ahora ubicado en una hornacina callejera en el hospital de San Juan de Dios- o el Cristo de la Paciencia de la parroquia de Santos Justo y Pastor, y en Jerez de la Frontera en el de la iglesia de la Santísima Trinidad; también se da el caso de aquellas imágenes que al modelo de Durero incorporan la columna de fuste alto, como las de Archidona, Osuna y Estepa.

El Cristo de la Humildad hace pareja con una Dolorosa zde vestir, la Virgen de los Dolores [11], que cabría fechar entre un cabildo de la hermandad de 1677 y otro de 1682, en que ya aparece citada $^{66}$, ocupando ambos los retablos del crucero de la iglesia del convento San José de carmelitas descalzos ${ }^{67}$. La aparición del nombre de Pedro de Mena entre los documentos de la cofradía así como la fecha de ejecución de

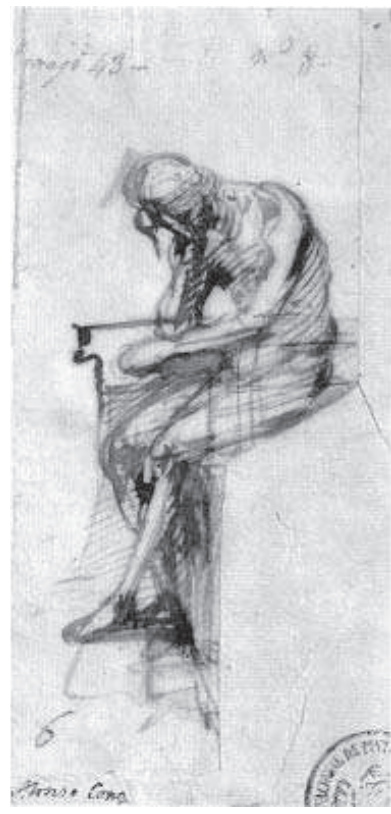

10. Anónimo. Cristo de la Humildad. Museo del Prado, Madrid. la imagen hicieron que en un primer momento se pusiera la imagen en relación con el escultor, fundamentalmente a raíz de los trabajos de conservación y restauración a los que fue sometida por Salvador Guzmán Moral, quien le devolvió su policromía original ${ }^{68}$. Esta atribución ha sido recogida por algunos autores no sin reservas ${ }^{69} \mathrm{y}$ de todo este corpus de imágenes es la que sin ninguna duda más problemas de vinculación al maestro plantea. La Dolorosa, una imagen de candelero con cabeza y manos de talla, recoge el tipo creado por Gaspar Becerra para los mínimos de Madrid, de Virgen doliente, con

66 LÓPEZ SALAMANCA, Francisco: «Notas para la historia de la Venerable Archicofradía de Nuestra Señora del Carmen (IV)». Carmelo de Pasión, 8, Lucena, 2002, pág. 22.

67 Es de lamentar que el Cristo y la Dolorosa fueran retirados de sus respectivos retablos hace unas décadas, por decisión del actual párroco. El Cristo fue confinado a un angosto recoveco a los pies de la iglesia que le origina algunos problemas de conservación.

68 GUZMÁN MORAL, Salvador: «Memoria de los trabajos de conservación y restauración de la Dolorosa del Carmen». Carmelo de Pasión, 8, Lucena, 2002, págs. 43-47 y «Consideraciones sobre Pedro de Mena y la posible autoría de la Dolorosa del Carmen de Lucena». Ibidem, págs. 49- 55.

69 En AA.VV.: Catálogo Artístico y Monumental..., t. V, tan sólo figura una fotografía de la misma. VILLAR MOVELLÁN, Alberto: Guía artística de la Provincia..., pág. 614 la denomina «Virgen de la Amargura» y aunque dice que es de escuela granadina del XVII, no ofrece atribución; ROMERO TORRES, José Luis: "La imaginería de Málaga...», pág. 433, la incluye entre las dolorosas atribuidas; VILLAR MOVELLÁN, Alberto, DABRIO GONZÁLEZ, María y RAYA RAYA, María Ángeles: Guía artística de Córdoba..., pág. 493, [«interesante imagen del XVII, cercana a Pedro de Mena»]. 


\begin{tabular}{|c|c|}
\hline EE & Manuel García Luque \\
\hline
\end{tabular}

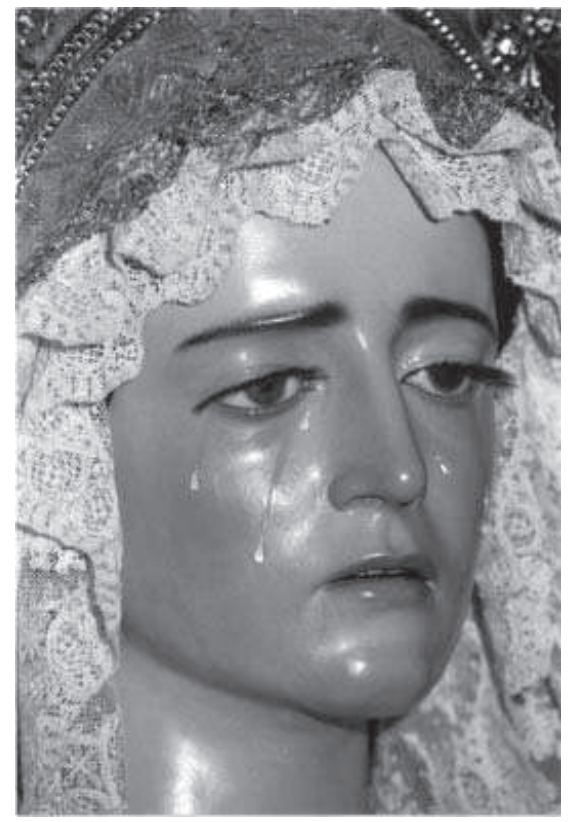

11. Círculo de Pedro de Mena (?). Ntra. Sra. de los Dolores (detalle), ca. 1677-1682. Iglesia parroquial de Ntra. Sra. del Carmen, Lucena.

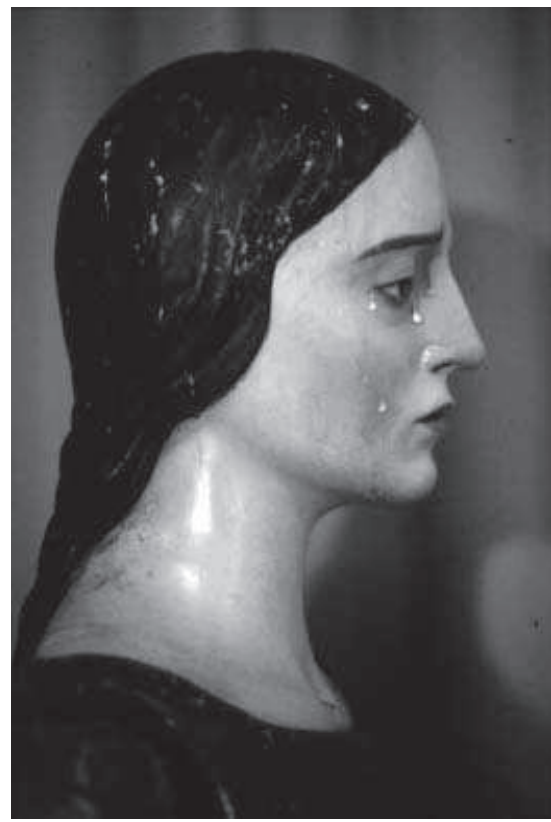

12. Círculo de Pedro de Mena (?). Ntra. Sra. de los Dolores (detalle), ca. 1677-1682. Iglesia parroquial de Ntra. Sra. del Carmen, Lucena.

las manos entrelazadas, para ser vestida, y que Cano difundió en Granada en su reproducción pictórica para una de las capillas de la catedral.

Su rostro, de una serena frontalidad y dolor contenido, está tratado con una gran delicadeza en la talla que se complementa con el efectismo verista de sus ojos de cristal y sus dientes de minuciosa talla. Aunque de perfil muy menoide [12], es pobre de expresión y tanto su plano frontal como sus grandes ojos, que no son almendrados, nos lo alejan de la producción del maestro. El pelo, escasamente tallado, está organizado en dos grandes guedejas que se recogen en la nuca para caer en un solo mechón por la espalda [13], curiosamente una de las zonas más trabajadas de la caballera. Sus manos entrelazadas, de delicada talla traen al recuerdo los bustos de Dolorosa de Mena, aunque fue una fórmula que por aquellas fechas comenzó a imponerse en las Dolorosas de vestir salidas de los talleres granadinos y malagueños. Mención especial merece su candelero [14], ornamentado con una fina decoración vegetal pintada, probablemente obra de algún fraile carmelita del convento, ya en el siglo XVIII.

Es cierto que tradicionalmente se han vinculado a Pedro de Mena algunas dolorosas de vestir, como la de la catedral de Sevilla o la desaparecida de la iglesia 


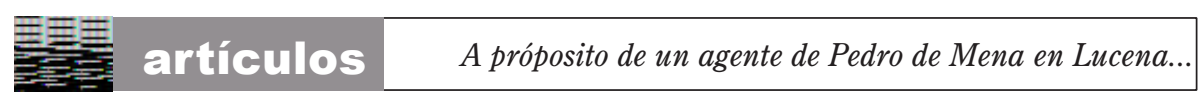

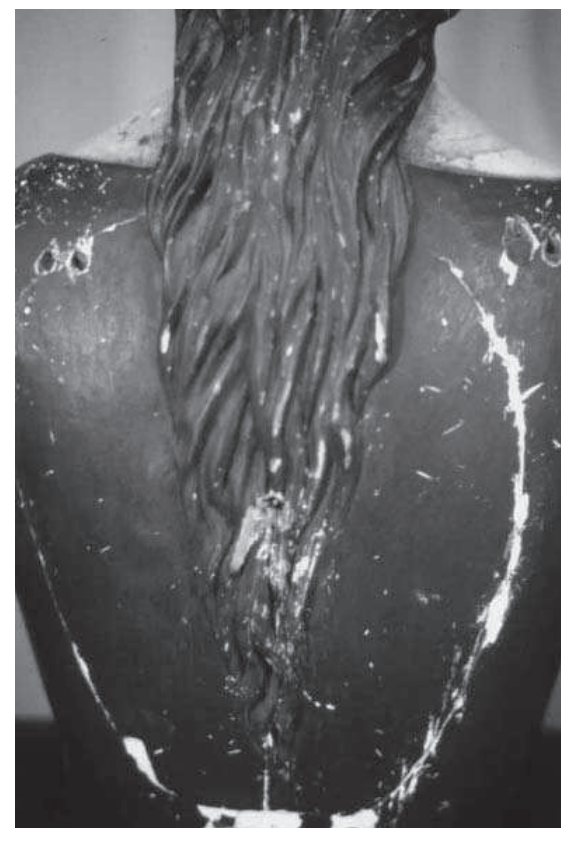

13. Círculo de Pedro de Mena (?). Ntra. Sra. de los Dolores (detalle cabellera), ca. 1677-1682. Iglesia parroquial de Ntra. Sra. del Carmen, Lucena.

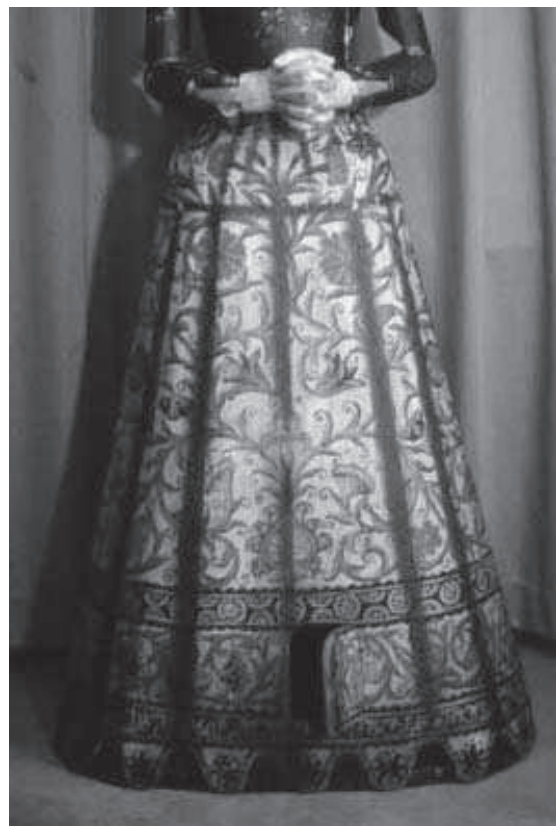

14. Círculo de Pedro de Mena (?). Ntra. Sra. de los Dolores (detalle candelero), ca. 1677-1682. Iglesia parroquial de Ntra. Sra. del Carmen, Lucena.

de los Mártires de Málaga, pero ninguna está documentada. Resulta difícil aceptar que un escultor como Mena, en la cima del éxito profesional desde la década de 1660 y con un amplio taller a su cargo se dedicara a tallar personalmente imágenes de candelero. Parece más lógico que, a lo sumo, fueran realizadas bajo su atenta supervisión por oficiales del taller, sometidos a las directrices y últimos retoques del maestro, mientras que Mena se ocuparía personalmente de aquellas esculturas que por sus características o por la importancia del comitente así lo requirieran. De este modo, cabría vincular la Dolorosa del Carmen con algún obrador malagueño de hacia 1680 o, quizás, con la producción de algún anónimo oficial del taller de Mena, reinterpretando, a distancia, los patrones formales del maestro.

Finalmente, este repaso de la obra del entorno de Mena en Lucena se cierra con un San Pedro Alcántara [14], en buen estado de conservación, que se encuentra en una capilla en el lado de la epístola de la iglesia del convento de la Madre de Dios de franciscanos observantes, precisamente la que fuera sede canónica de la antigua Cofradía de la Pasión y donde posiblemente se encontraba el Nazareno de Mena. De toda la serie de esculturas que Mena hizo del santo, la de Lucena sigue fielmente el 
modelo realizado para San Antón en Granada. El santo, de tamaño natural y con hábito franciscano, eleva su mirada al cielo, arrobado de éxtasis místico, mientras redacta su Tratado de la oración y meditación inspirado por el Espíritu Santo, que en forma de paloma aparece posado sobre su hombro. La figura adelanta su pierna derecha para dotar de corporeidad al pesado hábito, que se descompone en profundos pliegues originados a partir del triángulo invertido del torso, como es característico en Mena. Son muy significativas sus concomitancias con el San Pedro Alcántara que pertenecía a la Marquesa de Villadarias, evidentes por ejemplo en la presión que hace con el dedo corazón para sujetar el libro. De un realismo pasmoso es su esquelético rostro [15], demacrado y consumido por la extrema penitencia que practicaba este reformador franciscano, de quien Santa Teresa de Jesús llegó a afirmar que estaba «hecho de raíces». La cabeza demuestra una vez más la capacidad de Mena para abordar el tema de la ancianidad y su pericia en la talla, como avala el escaso aparejo empleado para las arrugas y la flacidez conseguida en la madera. No en balde Mena controlaba a la perfección el material, toda vez que había culminado con acierto la sillería coral de la catedral malagueña, empresa que exigía un total dominio de la técnica por su acabado en crudo, que imposibilitaba la enmienda de los defectos con el estucado, del mismo modo que cabe señalar la lección aprendida de su padre Alonso de Mena, quien en alguna ocasión también prescindió de la policromía, caso del Crucificado del Desamparo (1635) de la iglesia madrileña de San José.

La escultura fue dada como de Mena por Ramírez de Luque ${ }^{70}$, aunque la historiografía ha dubitado entre la atribución al maestro o a un seguidor ${ }^{71}$. Es cierto que la calidad en el plegado del hábito no se encuentra a la altura de otras versiones y que no se complementa con los típicos remiendos que Mena solía fingir en sus santos, argumentos que pueden ser rebatidos por el cada vez más importante peso del taller en la obra del granadino y por la posibilidad de que hubiera sido policromada por Illescas. A nuestro juicio es una obra indudablemente salida de su taller, con probable intervención del maestro en sus partes más logradas como la cabeza, que pudo llegar al convento en la década de 1670, justo después de la canonización del santo en 1669.

\section{Conclusiones.}

A modo de conclusión, resulta evidente que todavía queda mucho por recorrer para llegar a componer un catálogo coherente de la obra del pintor Bernabé Ximénez de Illescas, aunque con esta aportación hemos hecho una primera aproximación a su figura, fijando certeramente su fecha de nacimiento y arrojando un poco de luz

70 RAMÍREZ DE LUQUE, Fernando: Tardes divertidas, pág. 146.

71 En AA.VV.: Catálogo Artístico y Monumental..., t. V, pág. 179, se da como obra del escultor. Sin embargo, es considerada como obra de un seguidor en VILLAR MOVELLÁN, Alberto: Guía artística de la Provincia.... pág. 599 y VILLAR MOVELLÁN, Alberto, DABRIO GONZÁLEZ, María y RAYA RAYA, María Ángeles: Guía artística de Córdoba..., pág. 484. Lázaro Gila, gran conocedor de la obra del escultor, la considera de un seguidor. GILA MEDINA, Lázaro: Pedro de Mena..., pág. 128 n. 172. 


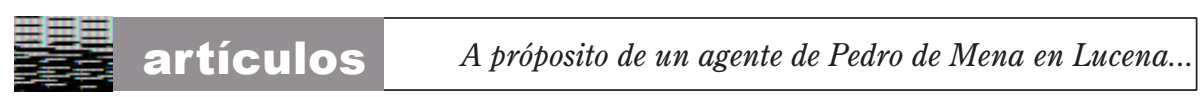

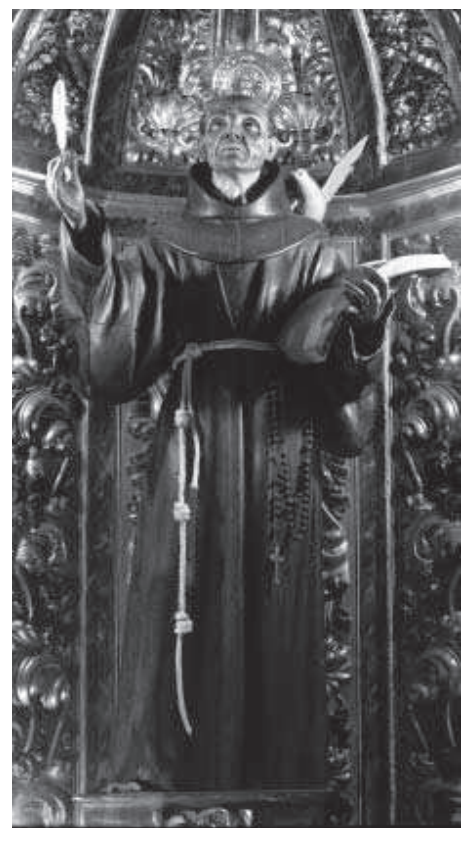

15. Pedro de Mena y taller (atribución). San Pedro Alcántara, ca. 1669-1678. Iglesia conventual de la Madre de Dios, Lucena.

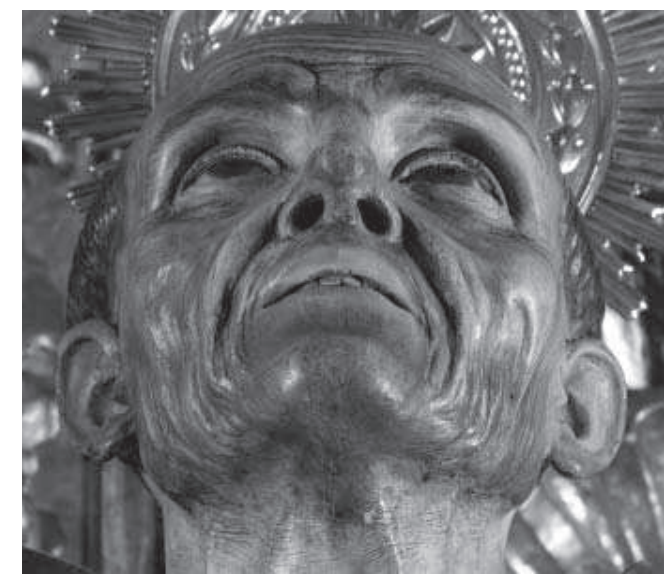

16. Pedro de Mena y taller (atribución). San Pedro Alcántara (detalle), ca. 1669-1678. Iglesia conventual de la Madre de Dios, Lucena.

sobre su biografía. Bien distinto es el caso del escultor granadino Pedro de Mena, pues desde la pionera monografía de Ricardo Orueta se ha avanzado mucho en el conocimiento de su vida y obra. Sin embargo, no es menos cierto que todavía se pueden formular nuevas claves interpretativas sobre su producción

y su taller, que ayuden a comprender el funcionamiento de las redes clientelares, los intermediarios como Illescas y, en definitiva, las circunstancias que permitieron la dispersión de su obra por buena parte de la geografía española e hispanoamericana, en especial durante sus años malagueños, en que su taller fue cobrando cada vez más peso para satisfacer la creciente demanda de encargos.

Se constata la recepción de un Nazareno y el deseo de realizar otras dos esculturas (un Niño Jesús y un Jesús Preso) para Lucena, aunque ninguna de ellas está localizada. Sin embargo, se ofrecen tres atribuciones que, si bien hasta el momento no han podido ser documentadas en archivo, deberían ser tenidas en cuenta para ser incorporadas al catálogo de obra atribuida del escultor. Al margen de seguir fielmente los modelos formales de Mena y estar apoyadas por interesantes indicios históricos que apuntan a su autoría, cuentan con un aval de excepción, como es la presencia en Lucena del pintor Bernabé Ximénez de Illescas, documentalmente relacionado con los talleres de dos grandes genios de la escultura, ambos Pedro, como fueron Mena y Roldán. 


\section{ApÉNDICE DOCUMENTAL.}

Carta de Bernabé Ximénez de Illescas a Pedro de Mena, sobre los problemas del Nazareno de la Cofradía de Pasión y el encargo de un Niño Jesús. Lucena, 29 de marzo de 1669.

Archivo de la Casa de los Tiros, Granada. Caja sin numerar.

[Cit. en ROMERO TORRES, José Luis: «El artista, el cliente y la obra de arte», en AA.VV.: Pedro de Mena, III centenario de su muerte 1688-1988 (cat. exp.). Málaga, Consejería de Cultura - Junta de Andalucía, 1989, pág. 99, n. 2]

Nota marginal: Mi Señor y mi amigo Pedro de Mena Medrano

Amigo y Señor. Dos e rrecibido de Vuestra Merced y no e respondido a ninguna hasta ahora que respondo y digo que en la pasada era escusado la respuesta puesto que se abia tomado resolución que se encarnase en Malaga. A esta no e respondido hasta ahora porque cuando me dieron la carta que fue abierta estrane el que Vuestra Merced la remitiera asi y fue a tiempo que ya estaba puesta la ymajen y hartos de berla todas la criaturas y almas que ai en esta ciudad, con que puesto que yo no soi de probecho para nada, ni balia mi boto, me estado en mi casa y no e ydo a verla hasta oi domingo dia de la fecha y es cierto que si no fuera si no fuera [sic] porque le di palabra al señor $D$. Antonio de la Cueba que iria a berla y porque era forçoso escribir a Vuestra Merced agradeciendole la merced que me hace en decirme que enmiende sus obras y rrespondo que sus obras de Vuestra Merced no necesitan de correccion de ningun artifice por grande que sea (ilegible) ni mas deva $/ \mathrm{N}^{\circ}$ tan corto ynjenio como el mio, demas que aunque yo fuera Micaelanjelo no hallara que enmendar si no dar a Vuestra Merced infinitas gracias y alabanças por lo bien que a hecho esta Santa Ymajen. Ya yo e dicho a estos Señores que bale ducientos ducados y sus mercedes esta en ese conocimiento y agradecidos, mas como no es obra particular sino de munchos no es posible satisfacer a Vuestra Merced su trabajo y cuidado. Yo de mi parte lo e estimado y lo estimo y creo Vuestra Merced que aunque estos señores anduvieron tan desatentos conmigo que al tienpo de enviar el dinero y de que se empeçara no me dieron cunta y lo hicieron por intrecesion de don Francisco Garrafa, con todo ello por Vuestra Merced y por sus galanterias, hiciera a Vuestra Merced un rregalo considerable. Ya se que Vuestra Merced no necesita de mis poquedades y miserias y sin enbargo lo hiciera si me hallara con posibilidad para hacerlo. Reciba Vuestra Merced mi grande boluntad y un eterno agradecimiento que es lo que puedo dar a Vuestra Merced, que si se ofreciere otra ocasion suplicare a Vuestra Merced me haga favor en cuanto a obra mas en el precio siempre lo dejare al gusto de Vuestra Merced de suerte que quede provechado = Estos señores, aunque la imagen esta tan buena, estan disgustados porque su intento era que echara la bendición en el paso que ase 
[y] a sido el intento principal y ya sea porque no se lo pidieron a Vuestra Merced o porque a Vuestra Merced se le olvido no se hiço con ese cuidado. Sientenlo muncho y en particular el señor D. Antonio de la Cueba que es la persona que mas fomenta esto Deudo del señor D. Feliciano de la Cueba a quien escribe su merced pidiendole solicite con Vuestra Merced el que haga otras manos luego al instante porque se han ponerse para el miercoles $/ r^{\circ}$ Santo que es cuando sale este santo Xristo en procesión. Yo suplico a Vuestra Merced si fuera posible que esto se haga, lo estimare muncho porque el trabajo de Vuestra Merced y el de estos señores quede con algun lucimiento y premio, me alegrare Vuestra Merced son haga fabor a todos. En cuanto a la paga de esto an dicho que si Vuestra Merced es servido de hacerlas que le davan estas para que las acomode en otra imajen y le haran un buen regalo. En esto de la paga ya digo a Vuestra Merced que no e de interbenir en nada y ansi Vuestra Merced ha en eso o quien fuere servido mas en suplicara Vuestra Merced que se haga, se lo suplico mi encarecidamente y conviene asi porque si Vuestra Merced no lo hace, an de enviar a otra parte que las haga [y] es echar a perder su imajen de Vuestra Merced. $Y$ para que bea que esto es verdad, algunos de los ermanos consultando el caso quisieron determinarse a que un ensanblador que ai aqui aserrara los dedos de la mano derecha para ponerlos en forma de bendicion y por amor de mi no lo han hecho y ansi buelbo a suplicar a Vuestra Merced que haga esto y si Vuestra Merced lo hace a de ser trocando las agçion de las manos, la que dobla a de ser la izquierda y la que alarga la derecha, que con que este como esta la izquierda estaba dispuesta para echar la bendicion cuando se ofrezca ha hacer el paso y luego volverla a poner la mano en la cruz = Tanbien suplico a Vuestra Merced sea servido de un niño que se an de pedir a Vuestra Meced que haga pa don Nicolas Salvador por mano del señor don Manuel Boço, que la haga Vuestra Merced con todo /

\section{[Al margen]}

primor porque es persona que lo entiende y dibuja alguna cosa y es hombre de buen gusto y tiene dineros con que se lo pagara a Vuestra Merced cuanto quisiere. Pidiome le suplicara a Vuestra Merced esto y ansi se lo suplico a Vuestra Merced y que me mande cuanto fuere de su gusto que siempre estare para servir a Vuestra Merced a quien Dios me guarde los años de mi deseo. Lucena y março 29 de 1669. De Vuestra Merced su servidor y amigo B. XM. D. I.

Suplico a Vuestra Merced me haga fabor de dar esta carta al señor don Juan Niño, nuestro amigo.

Bernabe Ximenez de Yllescas [firmado y rubricado] 
